\title{
Electrochemical profiling of multi-clad aluminium sheets used in automotive heat exchangers
}

\author{
Bordo, Kirill; C. Gudla, Visweswara ; Peguet, Lionel; Afseth, Andreas; Ambat, Rajan
}

\section{Published in:}

Corrosion Science

Link to article, DOI:

10.1016/j.corsci.2017.11.011

Publication date:

2018

Document Version

Peer reviewed version

Link back to DTU Orbit

Citation (APA):

Bordo, K., C. Gudla, V., Peguet, L., Afseth, A., \& Ambat, R. (2018). Electrochemical profiling of multi-clad aluminium sheets used in automotive heat exchangers. Corrosion Science, 131, 28-37. https://doi.org/10.1016/j.corsci.2017.11.011

\section{General rights}

Copyright and moral rights for the publications made accessible in the public portal are retained by the authors and/or other copyright owners and it is a condition of accessing publications that users recognise and abide by the legal requirements associated with these rights.

- Users may download and print one copy of any publication from the public portal for the purpose of private study or research.

- You may not further distribute the material or use it for any profit-making activity or commercial gain

- You may freely distribute the URL identifying the publication in the public portal 


\section{Manuscript Details}

\section{Manuscript number}

Title
CORSCI_2017_1486_R1

Electrochemical Profiling of Multi-Clad Aluminium Sheets used in Automotive Heat Exchangers

Full Length Article

\section{Article type}

Abstract

A combination of glow discharge optical emission spectroscopy sputtering and local electrochemical measurements was used to determine electrochemical changes upon brazing in a multi-layered Aluminium sheet (AA4343/AA3xxx/AA4343) with an additional low-Cu (AA3xxx) interlayer. Ecorr values from potentiodynamic polarization, galvanic corrosion behaviour by ZRA, microstructure and composition by SEM and TEM were investigated and compared to those obtained for sheet without the interlayer. Inward diffusion of Si from clad, and outward diffusion of $\mathrm{Cu}$ from core are found to degrade the corrosion properties of conventional sheet, whereas presence of interlayer reduced outward diffusion of $\mathrm{Cu}$ and hence improved corrosion protection.

\section{Keywords}

Taxonomy

Corresponding Author

Corresponding Author's Institution

Order of Authors
A. Aluminium; A. Intermetallics; B. SEM; B. Polarization; B. TEM;

Corrosion, Intermetallic, Elemental Analysis, Brazing, Microscopy, Aluminium

Visweswara Gudla

Technical University of Denmark

Kirill Bordo, Visweswara Gudla, lionel peguet, Andreas Afseth, Rajan Ambat

\section{Submission Files Included in this PDF}

File Name [File Type]

Cover Letter.docx [Cover Letter]

Response to Reviewer and Editor comments.docx [Response to Reviewers]

Highlights.docx [Highlights]

Graphical Abstract.pptx [Graphical Abstract]

Manuscript_R1.docx [Manuscript File]

List of Figures.docx [Figure]

Figures.pptx [Figure]

List of Tables.docx [Table]

Tables.pptx [Table]

To view all the submission files, including those not included in the PDF, click on the manuscript title on your EVISE Homepage, then click 'Download zip file'. 
To

J.M.C. Mol, $\mathrm{PhD}$

Editor-in-Chief

Corrosion Science

Dear Editor,

I have enclosed the revised version of the manuscript titled "Electrochemical Profiling of Multi-Clad Aluminium Sheets used in Automotive Heat Exchangers" with reference number CORSCI_2017_1486 after incorporating the suggestions and modifications from the review process. $\overline{\mathrm{I}}$ am also attaching a separate document listing the individual rebuttal and responses to the reviewer and editor comments.

I request you to kindly let me know the outcome of this revised submission or if any other information if required.

Yours Sincerely,

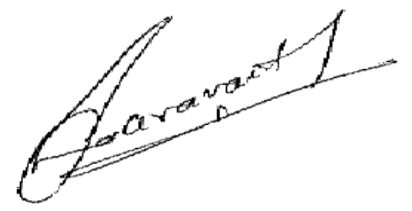

Visweswara Chakravarthy Gudla

Postdoctoral Research Fellow

Building 425, Materials and Surface Engineering

Department of Mechanical Engineering, Technical University of Denmark

Kongens Lyngby, 2800 Denmark

Tel +45 53803509 ,

Email: chakrigve@yahoo.co.in 
Ref: CORSCI_2017_1486

Title: Electrochemical Profiling of Multi-Clad Aluminium Sheets used in Automotive Heat Exchangers

Journal: Corrosion Science

Rebuttal to the comments from the editors and reviewers:

\section{Editor}

- Please find attached an annotated version of the manuscript submitted by reviewer 2 , please address accordingly in the revised manuscript.

The authors have incorporated the reviewer suggested modifications in the revised version of the manuscript.

\section{-Reviewer 1}

I don't understand the significance of table 3 which appears to be a compilation of own and literature results. Own results are based on EDS compositional analyses. The equilibrium stoichiometries appear to be listed. Have the authors tried to determine the phase structures by electron diffraction as part of their TEM investigations? Nonequilibrium variants of the phases can also be present. Is there a need for table 3 at all in reaching the objectives and conclusions of this work? It can perhaps be published separately as a review paper.

The table lists measured EDS composition of several intermetallic phases observed in the multiclad brazing sheets in as received, and brazed condition.

The measured concentrations are then related to possible phases (or family of phases) from literature for these material systems.

The authors have not determined the crystal structure of these phases using electron diffraction as it is out of the scope for the current paper.

Table 3 is presented in the manuscript to emphasize the fact that the precipitates formed after brazing in the interlayer region do contain some amount of Copper, which implies that the Cu content in the surrounding Aluminium solid solution is now reduced thus making it more anodic and more susceptible to galvanic coupling with intermetallic phases and corrosion.

In the author's opinion, this is essential to the discussion on lateral propagation of corrosion restricted to the interlayer region, and the conclusions presented in the manuscript.

The relevant text in the manuscript has now been modified accordingly to convey this in a better manner to the reader. 
Similar comments apply to the claim in the text that the $\mathrm{Al}_{2} \mathrm{Cu}$ phase may form during different types of thermomechanical treatment applied to the different types of surfaces investigated.

The manuscript has now been revised to exclude the comments on $\mathrm{Al}_{2} \mathrm{Cu}$ phases, as these were not characterized/investigated in this present work.

\section{-Reviewer 2}

This is high quality well presented work, the style requires some minor attention

The authors have incorporated the suggested modifications to the style in the revised version of the manuscript. 


\section{Highlights}

1. Microstructure and Local Electrochemistry of multiclad Aluminium sheets is studied.

2. Electrochemical potential difference between clad layers is reduced after brazing.

3. Intermetallic phases before and after brazing are characterized using TEM-EDS.

4. Low $\mathrm{Cu}$ interlayer reduces the negative effect of brazing and protects the core.

5. ZRA measurements show sacrificial nature of clad layers is reduced after brazing. 

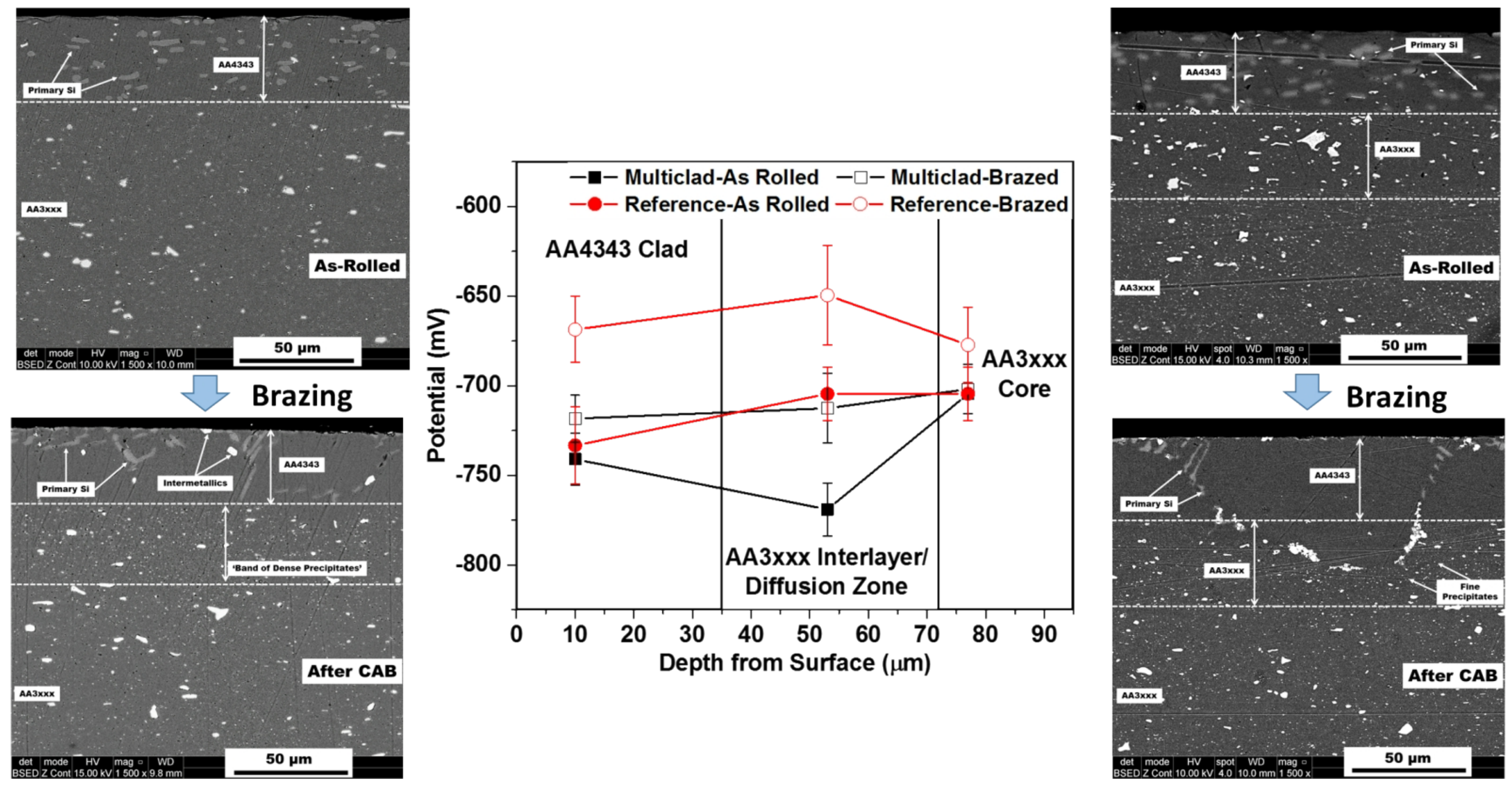


\title{
Electrochemical Profiling of Multi-Clad Aluminium Sheets used in Automotive Heat Exchangers
}

\author{
Kirill Bordo ${ }^{1}$, Visweswara C. Gudla ${ }^{*}$, Lionel Peguet ${ }^{2}$, Andreas Afseth $^{2}$, Rajan Ambat ${ }^{1}$ \\ ${ }^{1}$ Section of Materials and Surface Technology, Department of Mechanical Engineering, Technical University of \\ Denmark, Produktionstorvet, Kongens Lyngby, 2800, Denmark \\ ${ }^{2}$ Constellium Technology Center, Voreppe, 38341 France \\ *Corresponding Author: chakri_gvc@yahoo.co.in;vichg@mek.dtu.dk
}

\begin{abstract}
A combination of glow discharge optical emission spectroscopy sputtering and local electrochemical measurements was used to determine electrochemical changes upon brazing in a multi-layered Aluminium sheet (AA4343/AA3xxx/AA4343) with an additional low-Cu $(\mathrm{AA} 3 \mathrm{xxx})$ interlayer. $\mathrm{E}_{\text {corr }}$ values from potentiodynamic polarization, galvanic corrosion behaviour by ZRA, microstructure and composition by SEM and TEM were investigated and compared to those obtained for sheet without the interlayer. Inward diffusion of Si from clad, and outward diffusion of $\mathrm{Cu}$ from core are found to degrade the corrosion properties of conventional sheet, whereas presence of interlayer reduced outward diffusion of $\mathrm{Cu}$ and hence improved corrosion protection.
\end{abstract}

Keywords: A. Aluminium; A. Intermetallics; B. SEM; B. Polarization; B. TEM; 


\section{Introduction}

Aluminium and its alloys are widely used in the automotive, construction, and aerospace industries due to their high strength to weight ratio, inherent corrosion resistance, ease of formability, their ability to be surface modified for different functional applications and their ease of recycling [1-6]. Aluminium is used extensively in the automotive industry for heat exchangers in radiators, air conditioner evaporators, exhaust gas recirculation (EGR) and water and air charge air cooling (W \& A CAC) systems [7]. This is due to its favourable combination of mechanical, thermal, and electrochemical properties $[8,9]$. Over the last two decades, mechanical assembly in the production of heat exchangers has been continuously replaced by brazing due to its reduced manufacturing costs and compliance with the increased safety requirements and issues related to recyclability [10-12]. Brazed heat exchangers are manufactured from clad aluminium sheets where the high melting point core alloy provides the mechanical strength (typically an Al-Mn, AA3xxx), and the clad alloy with a low melting point such as Al-Si (AA4xxx) type alloy acts as a filler for the brazing process [13,14].

In EGR and ACAC systems, the use of aluminium alloys is limited due to corrosion by the exhaust gases, which are acidic in nature and contain water $[15,16]$. Corrosion occurring on the air side of heat exchanger tubes is a critical issue and is currently the main issue for continued down-gauging and weight reduction $[11,17,18]$. The conventional AA3xxx alloy used as core material in the heat exchanger tubes is prone to intergranular corrosion (IGC) and this results in penetration of the tube walls causing leakage and failure $[19,20]$. This corrosion is enhanced by diffusion of Si from the AA4xxx clad after brazing [21,22]. Afshar et al. [2325] studied the microstructure and electrochemical behaviour of brazed clad AA4xxx/AA3xxx sheets and observed that the presence of $\alpha-\mathrm{Al}(\mathrm{Fe}, \mathrm{Mn}) \mathrm{Si}$ intermetallic phases up to a depth of 5 $\mu \mathrm{m}$ below the surface sheet support galvanic coupling with the internal layers and enhance dissolution and IGC attack. It was postulated that elimination of these corrosion susceptible 
sites would improve corrosion performance. Recently, significant improvement in the air-side corrosion resistance has been achieved by using cladding of multiple layers of different $\mathrm{Al}$ alloys where the interlayer between the AA4xxx clad and the AA3xxx core acts as an additional sacrificial layer $[1,26]$. This approach allows for increased diffusion distances for $\mathrm{Si}$ and $\mathrm{Cu}$ from the AA4xxx clad and the AA3xxx core respectively, and thus is expected to prevent localised precipitation of $\mathrm{Al}(\mathrm{Fe}, \mathrm{Mn}) \mathrm{Si}$ intermetallic phases that contain $\mathrm{Cu}$. In addition, the $\mathrm{Cu}$ concentration gradient from the core to the clad is optimized and hence the electrode potential of the metal, and thus better corrosion protection properties of the core.

The objective of the present study was to understand the specific effect of an additional low- $\mathrm{Cu}$ AA3xxx interlayer on the microstructural and electrochemical modifications occurring in a clad Al heat exchanger sheet after being subjected to controlled atmosphere brazing treatment $(\mathrm{CAB}$, hereafter referred to as 'brazing'). In order to characterize the local changes in the electrochemical properties as a function of depth below the surface, a combination of controlled glow discharge optical emission spectroscopy (GDOES) sputtering [27] and localized electrochemical measurements [28-33] with a lateral resolution of $1 \mathrm{~mm}$ was employed. Electrochemical depth profiling of the clad Al structure with a low-Cu AA3xxx interlayer was studied before and after brazing. Zero resistance ammetry measurements were also performed by coupling the individual adjacent layers before and after brazing. The microstructural and compositional modifications were analysed by scanning and transmission electron microscopy and energy dispersive X-ray spectroscopy techniques. The results were correlated with the electrochemical depth profiling data and compared to those obtained for a conventional three-layer $\mathrm{Al}$ clad product without a low-Cu interlayer.

\section{Experimental Details}

\subsection{Materials}


Aluminium coupons of approximately $8 \mathrm{~cm}$ x $20 \mathrm{~cm}$ were cut from rolled brazing alloy sheet. The 'core' of the brazing sheet was a modified AA3xxx aluminium alloy, which had been clad with an AA4343 ( $\sim 36 \mu \mathrm{m}$ thick, 'clad') on the top of a low-Cu AA3xxx ( $\sim 38 \mu \mathrm{m}$ thick, 'interlayer') as shown in Figure 1 (a). For comparison, brazing sheet without the low-Cu interlayer was also analysed (Figure 1 (b)). The brazing sheet with the low-Cu interlayer is referred to as 'Multiclad' and those without the interlayer as 'Reference (Ref)'. The composition of the materials used in the as-rolled condition are shown in Table $\mathbf{1 .}$

\section{Figure 1}

Table 1

\subsection{Brazing}

The Al samples were degreased in acetone, dried and placed into a Controlled Atmosphere Brazing $(\mathrm{CAB})$ furnace in a dry, inert nitrogen gas atmosphere for simulating the temperature cycle during the brazing treatment. The materials were heated up to $600{ }^{\circ} \mathrm{C}$ (at 30 ${ }^{\circ} \mathrm{C} / \mathrm{min}$ ), and were held at that temperature for $2 \mathrm{~min}$. and then cooled down at a specified rate of $60{ }^{\circ} \mathrm{C} / \mathrm{min}$. The process temperature was selected to be close to the liquidus temperature of the clad material $\left(\sim 612{ }^{\circ} \mathrm{C}\right)$ and much lower than the solidus temperature of the core material $\left(\sim 640{ }^{\circ} \mathrm{C}\right)[11,34]$.

\subsection{RF-GDOES}

Both the as-rolled, and brazed sheet materials were then etched to certain depths by Argon ion sputtering using radio frequency glow discharge optical emission spectroscopy (RFGDOES, GD-Profiler 2, Horiba Jobin Yvon). The applied sputter power was $40 \mathrm{~W}$ and the Ar pressure in the sputtering chamber was $650 \mathrm{~Pa}$. The diameter of the sputter crater was $4 \mathrm{~mm}$. The compositional depth distributions of the main alloying elements ( $\mathrm{Si}, \mathrm{Cu}, \mathrm{Fe}$ and $\mathrm{Mn}$ ) in the sheet materials were used to identify the interfaces between the individual cladding layers and to define the required sputtering depth for further electrochemical depth profiling analysis. 


\subsection{Electrochemical Behaviour}

The electrochemical behaviour of both the as-rolled, and brazed materials was determined at different depths using a Dualscope EC localized electrochemical cell (Semilab Germany $\mathrm{GmbH}$, formerly DME Nanotechnologie GmbH, Germany) having a small opening (1 mm diameter plastic pipette tip) which ensured the contact between the electrolyte and the working electrode (see Figure 2). The system employed an electrochemical head consisting of the reference and counter electrodes, which were open to a reservoir cavity containing the electrolyte. A plastic pipette tip with $1 \mathrm{~mm}$ diameter opening was attached to this reservoir cavity to create a hanging droplet of the electrolyte onto the test surface. The hanging droplet was achieved by the precise airtight solution pumping mechanism. The size and shape of the droplet were continuously monitored and controlled using a microscope and a digital video camera attached to the cell $[23,35,36]$. Prior to each experiment, a small amount of solution was always dispersed from the tip followed by gentle cleaning by scrubbing against a flat surface. The tip was then brought into contact with the surface of the working electrode and then slowly retracted to a height of $100 \mu \mathrm{m}$ from the surface of the working electrode. The hanging droplet of the electrolyte (of $1 \mathrm{~mm}$ diameter) is achieved due to surface tension, and guarantees wetting of the working electrode surface while maintaining the size and shape of the droplet.

For all the electrochemical measurements a saturated $\mathrm{Ag} / \mathrm{AgCl}$ reference electrode and a Pt wire counter electrode were used. Potentiodynamic polarization scans were performed with a scan rate of $1 \mathrm{mV} / \mathrm{s}$. Prior to each measurement, the open circuit potential (OCP) was allowed to stabilize for $30 \mathrm{~min}$. A solution of $0.1 \mathrm{M} \mathrm{HCl}(\mathrm{pH} \sim 1$, analytical grade) was used as the electrolyte based on a parametric study by Peguet et al. [37,38] which compared the use of ASTM G69 solution (1M NaCl $\left.+\mathrm{H}_{2} \mathrm{O}_{2} 9 \mathrm{~mL} / \mathrm{L}\right)$ [39] with $0.1 \mathrm{M} \mathrm{HCl}$. Results showed that the $1 \mathrm{M} \mathrm{NaCl}$ based electrolyte was very aggressive and penetrating pits of more than $100 \mu \mathrm{m}$ depth 
were formed which was not suitable for thin gauge sheets. Lower $\mathrm{Cl}$ concentration with use of $0.1 \mathrm{M} \mathrm{NaCl}$ resulted in longer time for stabilization of potential. The $0.1 \mathrm{M} \mathrm{HCl}$ solution allowed faster de-passivation of the surface and stabilising of the surface potential. All experiments were conducted at room temperature and no aeration was applied to the electrolyte.

\section{Figure 2}

Zero Resistance Ammetry (ZRA) measurements were performed in a conventional 3electrode cell using the same potentiostat. The measurements were conducted in a $0.1 \mathrm{M} \mathrm{NaCl}$ solution of $\mathrm{pH} 2.8$ (adjusted with $\mathrm{HCl} ; 400 \mathrm{~mL}$ volume electrolyte) at room temperature for 3 $\mathrm{h}$ to determine the evolution of the galvanic current density between the individual layers in the brazing sheet and the galvanic potential. These measurements were conducted before and after the brazing treatment. In each ZRA experiment, two pieces of the similar sheet material which had been sputtered to different depths by GDOES were used. This allows for coupling between the clad (WE1) and the interlayer (WE2); and the interlayer (WE1) and the core (WE2). Only the sputtered craters (of $4 \mathrm{~mm}$ diameter, $12.56 \mathrm{~mm}^{2}$ area; surface area ratio 1:1) were exposed to the electrolyte in the ZRA setup, and the remaining surface of each sample was covered with a protective lacquer. The samples (electrodes) were placed facing each other and the distance between the anode and the cathode was $5 \pm 0.5 \mathrm{~cm}$. The potentiodynamic polarization tests and the ZRA testes were repeated at least three times.

\subsection{Microstructural Characterization}

The microstructures of the as-rolled, and brazed materials were examined using a scanning electron microscope (SEM, Quanta 200 ESEM FEG, FEI) equipped with an energy dispersive X-ray spectrometer (EDS, $80 \mathrm{~mm}^{2}$ X-Max silicon drift detector, Oxford Instruments). Additional characterization of the microstructure before and after brazing was performed using a transmission electron microscope (TEM, Tecnai T20 G2, FEI) coupled to an 
energy dispersive X-ray spectrometer (EDS, $80 \mathrm{~mm}^{2}$ X-Max silicon drift detector, Oxford Instruments). Samples for TEM analysis were prepared using site specific in-situ lift out of 1 $\mu \mathrm{m}$ thick lamella from the cross section of the Al sheets using a dual beam focused ion beam microscope (FIB-SEM, Helios EBS3, FEI) [40-44]. For the in-situ lift out procedure, a Pt layer ( $3 \mu \mathrm{m}$ thick) was deposited onto the region of interest to protect the underlying sample surface from high energy ion milling. A Ga liquid metal ion source was employed for focused ion beam milling of the sample, and a Mo TEM grid was used for mounting the TEM lamella that was lift out from the region of interest using Pt deposition as a means to weld the lamella to the Mo grid. The lamella were further thinned down to $\sim 120 \mathrm{~nm}$ thickness for electron transparency using focused ion beam milling, and final milling was performed using low energy ion beam milling $(2 \mathrm{keV})$ to remove any high energy milling induced artefacts. The EDS analysis on the thin lamella was performed in the TEM, and the quantification of the elements was done after deconvolution of $\mathrm{C}, \mathrm{Ga}, \mathrm{Pt}$ and Mo that arise due to the sample preparation using EDS software coupled to the TEM (Aztec EDS TEM, Oxford Instruments).

\section{Results and Discussion}

\subsection{Elemental depth profiling by GDOES}

\section{Figure 3}

Figure 3 shows the compositional elemental depth profiles of $\mathrm{Si}, \mathrm{Fe}, \mathrm{Mn}$, and $\mathrm{Cu}$ for the as-rolled (AR) and brazed (BZ) sheets. For the as-rolled sheets, the drastic decrease in the concentration of $\mathrm{Si}$, and increase in the concentration of $\mathrm{Mn}$ after approx. 8 min of sputtering in Figure 3 (a) corresponds to the interface between the clad AA4343 layer and the AA3xxx core. Similar behaviour is observed in Figure 3 (b) indicating the interface between the AA4343 clad and AA3xxx interlayer. The increase in the concentration of $\mathrm{Cu}$ after $\sim 20$ min of sputtering 
indicates the transition across the interface between the AA3xxx interlayer and the AA3xxx core material.

Table 2

The surface regions of the as-rolled sheets are slightly enriched with $\mathrm{Si}$, while in the deeper layers of AA4343 the concentration of Si is almost constant ( 5.5 wt.\%). After brazing, the concentration of Si next to the surface is dramatically increased (up to $42 \mathrm{wt} . \%$ ) and the interfaces between the individual layers are not well defined. The change in concentration of $\mathrm{Mn}$ in the individual layers after brazing is weak when compared to that of $\mathrm{Si}$ and $\mathrm{Cu}$. This is due to the limited diffusion of $\mathrm{Mn}$ in this system under brazing conditions. Overall, the brazing treatment has caused inward diffusion of the Si from the top layer into the AA3xxx interlayer and outward diffusion of $\mathrm{Mn}$ to a lower extent into the AA4343 layer. Similar trends are observed for $\mathrm{Cu}$, which diffuses from the AA3xxx core to the surface layers, and Fe from the AA3 $x x x$ interlayer. It is interesting to note that most of the Fe from the interlayer is found to be localized at a certain depth in the brazed multiclad sheets.

In order to expose different layers of the material for electrochemical investigation, the as-rolled and brazed sheets were sputtered for different time intervals. These time intervals are marked by arrows in Figure 3. The representative compositions corresponding to these sputtered depths before and after brazing are summarized in Table 2.

\subsection{Microstructural Analysis}

The microstructure of the multiclad sheets before and after brazing is shown in Figure 4. The multiclad sheet in as rolled condition shows distinct layers of different materials with different size, shape, and morphology of constituent/intermetallic particles (Figure 4 (a), (b)). The AA4343 clad shows primary Si particles in the Al matrix. Both the AA3xxx interlayer and the AA3xxx core shows bright intermetallic particles of a few micron in size in addition to submicron sized particles. The EDS analysis performed (not shown here) on the individual bigger 
intermetallics reveals the presence of $\mathrm{Al}, \mathrm{Si}, \mathrm{Mn}$ and $\mathrm{Fe}$, while the smaller particles showed presence of $\mathrm{Al}, \mathrm{Si}, \mathrm{Mn}, \mathrm{Fe}$ and $\mathrm{Cu}$. The multiclad sheets that are subjected to brazing do not show any distinct interfaces between the clad layers (Figure 4 (c), (d)). In addition, the primary Si particles have re-distributed and appear as dendrites after the melting of the AA4343 clad and re-solidification. The primary Si now is mostly present at the top surface of the resolidified clad [45] and also at the grain boundaries, which is associated with other bright intermetallic particles that are precipitated along the grain boundaries in the form of a 'band of dense precipitates' (Figure 4 (d) and (f)). The interface between the clad and the interlayer appears to have moved inwards (Figure 4 (d)). The band of dense precipitates in the reference sheet after brazing has been observed by others $[1,46]$ and is generally associated as the reason for enhanced galvanic coupling and corrosion of the brazed clad sheets. The higher number of the cathodic intermetallic phases combined with lower dissolved $\mathrm{Cu}$, and $\mathrm{Mn}$ in the surrounding $\mathrm{Al}$ matrix promote dissolution of the $\mathrm{Al}$ matrix and result in corrosion propagation through the inner layers of the brazed material [47].

\section{Figure 4}

In order to analyse the microstructure and the constituent phases in detail, transmission electron microscopy was performed on the as rolled and brazed multiclad sheet materials. Samples were prepared as explained in the experimental section using focused ion beam milling and lift out. The sample areas were chosen from the interface of the clad and the interlayer (Figure $5(\mathrm{a})$ ); and interlayer and the core for the as rolled material (Figure 5 (b)). For the brazed multiclad sheets, samples were prepared from similar locations corresponding to equal depth from the surface as that for the as rolled samples (see Figure 5 (c) and (d)).

\section{Figure 5}


The interface between the AA4343 clad and the AA3xxx interlayer can be clearly seen in Figure 5 (a). The AA3xxx interlayer is characterised by a homogenous distribution of very fine precipitates with a spheroidal shape. The average size of these precipitates is in the order of 150-200 $\mathrm{nm}$. In addition, there are intermetallic (constituent) particles in the micrometre size range. The structure of the AA3xxx core can be seen in Figure 5 (b) and is characterized by the presence of sub-micron size precipitates with cuboidal morphology, and are elongated in one direction. The precipitates found in the interlayer are finer than those found in the AA3xxx core.

As can be seen from the images in Figure 5 (c) and (d), the interface cannot be clearly delineated after brazing of the multiclad sheets. However, the AA3xxx interlayer retains the fine spheroidal precipitates as seen in Figure 5 (c). The interface of the clad and the interlayer here displays the nature of the dense band of precipitates observed in Figure 4 (d). A dark appearing intermetallic particle of the size of a micron is observed, the boundary of which with the surrounding Al matrix is decorated with very dense distribution of fine precipitates. Though not clearly visible, the intermetallic particle has formed at the boundary between the Al matrix and a primary Si particle (marked at top left corner of the image in Figure 5 (a)) which is formed after the melting and re-solidification of the AA4343 clad. In addition there is a 'precipitate free zone' in the areas around the bigger intermetallic phases. This is due to the dissolution of the fine Al-Mn dispersoids from the Al matrix and diffusion and preferential formation of AlFe-Mn-Si phases at the band of dense precipitates [48]. The interface between the interlayer and the core after brazing shows very little number of fine precipitates. This corresponds to the region in the brazed multiclad sheet that is just below the previously existing interface between the interlayer and core (see Figure 4 (d)). The SEM images also show a narrow zone below the interface, which has a very low density of precipitates. 
Combining the images in Figure 4 and Figure 5, it is clear that the number density of the fine intermetallic particles is lower, and the bigger intermetallics is higher in the as-rolled AA3xxx interlayer when compared to that in AA3xxxx core (Figure 4 (b)). In addition, the brazing treatment has caused the number density of fine sub-micron sized precipitates to increase and that of the bigger intermetallic particles to reduce in the AA3xxx interlayer. A closer look at the structure of AA3xxx core before and after brazing also reveals a reduction in the number density of the fine sub-micron sized precipitates (Figure 4 (b), (d)) just below the interface with the AA3xxx interlayer. The EDS (TEM) analysis performed on individual features observed in the different layers of the multiclad sheet in as rolled and brazed condition and the summary of the analysis is shown in Table 3 [49-52]. The general observation from comparing the compositions of different precipitates at different depths from the surface before and after brazing is that the intermetallic (constituent) phases and the fine dispersoids in brazed structure show presence of $\mathrm{Cu}$ unlike the AA3xxx interlayer before brazing. Formation of these numerous precipitates that contain $\mathrm{Cu}$ upon brazing causes loss of dissolved $\mathrm{Cu}$ (diffusing outwards from the core to the interlayer) from the $\mathrm{Al}$ matrix, which in turn makes the $\mathrm{Al}$ matrix in the interlayer region more anodic compared to the intermetallic phases that are formed and thus more susceptible to corrosion compared to the core Al matrix.

\section{Table 3}

\subsection{Electrochemical measurements}

The potentiodynamic anodic polarization scans obtained in $0.1 \mathrm{M} \mathrm{HCl}$ solution for the reference and multiclad sheet materials in as-rolled, and brazed conditions are shown in Figure 6. The scans for different depths are recorded from the surfaces obtained by controlled sputtering using GDOES to different depths as mentioned in Figure 3. The anodic current densities (see Figure 6) for the clad sheet remains unchanged for the multiclad sheet when 
compared to the reference sheet after brazing. For the interlayer, the anodic current density at a given potential is lower after brazing than in as-rolled condition. The scans do not display any significant passive regions during anodic polarization due to the highly acidic nature of the electrolyte. The key factor for assessing the corrosion protection ability of the clad and the interlayer can be deduced from the $\mathrm{E}_{\text {corr }}$ values of the individual layers before and after brazing.

\section{Figure 6}

\section{Figure 7}

Figure 7 shows the $\mathrm{E}_{\text {corr }}$ values obtained from potentiodynamic polarization measurements for the individual layers before and after brazing. The $\mathrm{E}_{\text {corr }}$ values for the AA4343 clad and the AA3xxx interlayer in as-rolled condition are lower than that measured for the AA3xxx core. The interlayer is the most anodic of the three different layers in the multiclad sheet in as rolled condition. The brazing treatment of the multiclad sheet raises the potential of the clad (approx. $25 \mathrm{mV}$ ) and the interlayer (approx. $50 \mathrm{mV}$ ), but does not greatly affect the AA3xxx core. The AA3xxx interlayer now shows a higher potential than the AA4343 clad, but is still anodic when compared to the brazed AA3xxx core. The reference sheets without the interlayer also show an increase in the potential for the AA4343 clad after the brazing treatment. The increase in potential is higher for the clad in the reference material (approx. $60 \mathrm{mV}$ ) when compared to that in the multiclad sheet (approx. $25 \mathrm{mV}$ ) due to higher $\mathrm{Cu}$ diffusion towards the surface in the absence if an interlayer. In addition, the potential for the AA3xxx core in the diffusion zone has increased significantly when compared to the bulk of the core (approx. $25 \mathrm{mV}$ ). In terms of depth below the interface with the core, the reference sheet shows considerably higher potential values (approx. $-650 \mathrm{mV}$ vs. saturated $\mathrm{Ag} / \mathrm{AgCl}$ ) when compared to that of the multiclad sheet (approx. $-700 \mathrm{mV}$ vs. saturated $\mathrm{Ag} / \mathrm{AgCl}$ ) upon brazing. 
Figure 8 shows the evolution of galvanic current density and galvanic potential vs. time obtained from the ZRA measurements performed by coupling the AA4343 clad with the AA3xxx interlayer; and the AA3xxx interlayer with the AA3xxx core for the multiclad sheets in as-rolled (Figure 8 (a)) and brazed conditions (Figure 8 (b)). Results show that in the asrolled condition, the clad is anodic to the interlayer which is in turn anodic to the core material. This is expected to provide sacrificial protection to the core by the top layers. The brazing treatment has modified this and it can be observed that there is no longer a clear observable trend in the current flow between the adjacent layers in the multiclad material. The results observed here are generally in accordance with the $\mathrm{E}_{\text {corr }}$ values obtained from localized electrochemical measurements in Figure 7 with exception for the relative $\mathrm{E}_{\text {corr }}$ values between the clad and the interlayer in as rolled condition.

\section{Figure 8}

In general, the electrochemical profiling and microstructural analysis performed here indicates that presence of a low-Cu interlayer in between the clad and the core modifies the changes occurring during the brazing process in terms of the evolution of microstructure due to diffusion based phenomenon and also the local electrochemical nature of the different layers. During brazing, Si from the AA4343 clad diffused inwards to the low-Cu AA3xxx interlayer (Figure 3) which caused the Mn from the solution along with the Fe in the interlayer to precipitate out as $\mathrm{Al}(\mathrm{Fe}, \mathrm{Mn}) \mathrm{Si}$ based precipitates [48,53,54] (Figure 4 (d)). The interfacial region between the resolidified clad and the interlayer displayed the highest density of such precipitates. Similarly, precipitation also took place at the interface between the AA3xxx core and the resolidified AA4343 clad for the reference sheets which do not have an interlayer. However, in this case outward diffusion of $\mathrm{Cu}$ along with $\mathrm{Mn}$ from the core towards the clad promoted precipitation of $\mathrm{Al}(\mathrm{Fe}, \mathrm{Mn}, \mathrm{Cu}) \mathrm{Si}$ based precipitates (see Table 3) [55-58]. This resulted in depletion of $\mathrm{Cu}$ and $\mathrm{Mn}$ as solute in the $\mathrm{Al}$ matrix in the core material for the 
reference sheets. In the case of the presence of a low- $\mathrm{Cu}$ interlayer, the $\mathrm{Cu}$ diffused outwards from the core to the low- $\mathrm{Cu}$ interlayer, which restricted the formation of the $\mathrm{Cu}$ containing precipitates to the interlayer region. As the Si diffusion from the clad up to the core is not significant, $\mathrm{Cu}$ in core material is retained in the $\mathrm{Al}$ solution to a higher extent. This is observed in the RF-GDOES profiles for the reference and multiclad sheets before and after brazing in Figure 3 as well as in Table 3.

The local electrochemical analysis showing the $\mathrm{E}_{\text {corr }}$ values for the various layers before and after brazing process (Figure 7) along with the ZRA measurements (Figure 8) reveal that the AA3xxx core in as-rolled condition is cathodic when compared to the AA4343 clad as well as to the low- $\mathrm{Cu}$ AA3xxx interlayer. This is due to higher $\mathrm{Mn}$ and $\mathrm{Cu}$ in the core and lower $\mathrm{Cu}$ in the interlayer [59]. The AA4343 clad is designed to act as a sacrificial layer for allowing corrosion to propagate through the clad and protect the core material. However, upon brazing due to the outward diffusion of $\mathrm{Cu}$ from the core material, the $\mathrm{E}_{\text {corr }}$ value of the resolidified clad increases thus lowering the gap between the $\mathrm{E}_{\text {corr }}$ values of the core and the clad. The formation of $\mathrm{Al}(\mathrm{Fe}, \mathrm{Mn}, \mathrm{Cu}) \mathrm{Si}$ precipitates which are cathodic in nature when compared to the $\mathrm{Al}$ matrix enhances the potential difference between these materials and allows for galvanic coupling and corrosion propagation between the matrix and the precipitates [60-67] even though the overall $\mathrm{E}_{\text {corr }}$ value is higher.

In the case of presence of a low-Cu interlayer, the $\mathrm{Cu}$ diffusing out from the core to the interlayer formed $\mathrm{Cu}$ based precipitates in the interlayer region. However, the $\mathrm{Cu}$ in the core material remained in the $\mathrm{Al}$ matrix to a higher extent due to lower available diffused Si from clad restricting precipitation [11]. An increasing concentration of dissolved $\mathrm{Cu}$ with depth due to outward diffusion from core material also results in an increasing (shift towards positive direction) potential of the Al matrix towards the core. This protects the core material as the corrosion propagation faces $\mathrm{Al}$ material that is more cathodic with depth from the surface thus 
promoting lateral corrosion within the interlayer region and preventing through failure. In addition, the formation of the precipitates upon brazing at the grain boundaries as shown in Figure 5 (c) also restricts the corrosion to propagate laterally. The effect of higher $\mathrm{Cu}$ in solution of the core material due to the added low-Cu interlayer improves the corrosion protection of the core layer thus enhancing the life of the brazed multi-clad sheets when compared to those without a low-Cu interlayer.

\section{Conclusions}

In the present work, a combination of micro-scale electrochemical measurements and glow discharge optical emission spectroscopy was used to investigate the electrochemical properties of multi-clad Al structures as a function of local alloy composition and microstructure before and after brazing. In general, the obtained results reveal that:

1. Brazing of the clad Al sheet material leads to inwards diffusion of Si from the clad and outwards diffusion of $\mathrm{Cu}$ from the core forming a band of dense precipitates.

2. The difference between the electrode potentials and hence the corrosion protection provided to the core by the outer layers is reduced after brazing.

3. The addition of a low- $\mathrm{Cu}$ interlayer reduces the formation of $\mathrm{Al}(\mathrm{Fe}, \mathrm{Mn}, \mathrm{Cu}) \mathrm{Si}$ based phases in the band of dense precipitates and helps retain the cathodic nature of the core compared to the outer layers after brazing.

4. ZRA measurements show that the clad and the interlayer are anodic when compared to the core in as rolled condition but no clear distinction can be made after brazing treatment. 


\section{References}

[1] W.S. Miller, L. Zhuang, J. Bottema, A.J. Wittebrood, P. De Smet, A. Haszler, A. Vieregge, Recent development in aluminium alloys for the automotive industry, Mater. Sci. Eng. A. 280 (2000) 37-49. doi:10.1016/S0921-5093(99)00653-X.

[2] V.C. Gudla, S. Canulescu, R. Shabadi, K. Rechendorff, K. Dirscherl, R. Ambat, Structure of anodized Al-Zr sputter deposited coatings and effect on optical appearance, Appl. Surf. Sci. 317 (2014) 1113-1124. doi:10.1016/j.apsusc.2014.09.037.

[3] R.U. Din, V.C. Gudla, M.S. Jellesen, R. Ambat, Accelerated growth of oxide film on aluminium alloys under steam: Part I: Effects of alloy chemistry and steam vapour pressure on microstructure, Surf. Coatings Technol. 276 (2015) 77-88. doi:10.1016/j.surfcoat.2015.06.059.

[4] T. Dursun, C. Soutis, Recent developments in advanced aircraft aluminium alloys, Mater. Des. 56 (2014) 862-871. doi:10.1016/j.matdes.2013.12.002.

[5] G. Gaustad, E. Olivetti, R. Kirchain, Improving aluminum recycling: A survey of sorting and impurity removal technologies, Resour. Conserv. Recycl. 58 (2012) 79-87. doi:10.1016/j.resconrec.2011.10.010.

[6] S.T. Abrahami, J.M.M. de Kok, V.C. Gudla, R. Ambat, H. Terryn, J.M.C. Mol, Interface strength and degradation of adhesively bonded porous aluminum oxides, Npj Mater. Degrad. 1 (2017) 8. doi:10.1038/s41529-017-0007-0.

[7] G.S. Cole, A.M. Sherman, Light weight materials for automotive applications, Mater. Charact. 35 (1995) 3-9. doi:10.1016/1044-5803(95)00063-1.

[8] R.N. Lumley, Introduction to Aluminium Metallurgy, in: R.B.T.-F. of A.M. Lumley (Ed.), Woodhead Publ. Ser. Met. Surf. Eng., Woodhead Publishing, 2011: pp. 1-19. doi:http://dx.doi.org/10.1533/9780857090256.1.

[9] A. E., N. Birbilis, J. M.C., S. J., X. Zhou, G. E., High Strength Al-Alloys: Microstructure, 
Corrosion and Principles of Protection, in: Recent Trends Process. Degrad. Alum. Alloy., InTech, 2011: pp. 223-262. doi:10.5772/18766.

[10] P. Roberts, Brazing Aluminum, in: Ind. Brazing Pract., CRC Press, 2013: pp. 261-298. doi:doi:10.1201/b14061-10.

[11] H. Zhao, R. Woods, 10 - Controlled atmosphere brazing of aluminum, in: D.P.B.T.-A. in B. Sekulić (Ed.), Woodhead Publ. Ser. Weld. Other Join. Technol., Woodhead Publishing, 2013: p. 280-323e. doi:http://dx.doi.org/10.1533/9780857096500.2.280.

[12] J. Cui, H.J. Roven, Recycling of automotive aluminum, Trans. Nonferrous Met. Soc. China. 20 (2010) 2057-2063. doi:http://dx.doi.org/10.1016/S1003-6326(09)60417-9.

[13] S. Lathabai, 20 - Joining of aluminium and its alloys, in: R.B.T.-F. of A.M. Lumley (Ed.), Fundam. Alum. Metall. Prod. Process. Appl., Woodhead Publishing, 2011: pp. 607-654. doi:http://dx.doi.org/10.1533/9780857090256.3.607.

[14] R.W. Messler Jr., 8 - Brazing BT - Joining of Advanced Materials, in: ButterworthHeinemann, Boston, 1993: pp. 283-312. doi:http://dx.doi.org/10.1016/B978-0-75069008-9.50011-7.

[15] Z. Dan, I. Muto, N. Hara, Effects of environmental factors on atmospheric corrosion of aluminium and its alloys under constant dew point conditions, Corros. Sci. 57 (2012) 22-29. doi:10.1016/j.corsci.2011.12.038.

[16] I. Boukerche, S. Djerad, L. Benmansour, L. Tifouti, K. Saleh, Degradability of aluminum in acidic and alkaline solutions, Corros. Sci. $78 \quad$ (2014) 343-352. doi:10.1016/j.corsci.2013.10.019.

[17] R. Bonzom, R. Oltra, Intergranular corrosion propagation rate of 2024 alloy investigated via the "one-dimensional artificial pit" technique, Corros. Sci. 111 (2016) 850-855. doi:10.1016/j.corsci.2016.05.033.

[18] J. Soltis, Passivity breakdown, pit initiation and propagation of pits in metallic materials 
- Review, Corros. Sci. 90 (2015) 5-22. doi:10.1016/j.corsci.2014.10.006.

[19] G.J. Marshall, R.K. Bolingbroke, A. Gray, Microstructural control in an aluminum core alloy for brazing sheet applications, Metall. Trans. A. 24 (1993) 1935-1942. doi:10.1007/BF02666328.

[20] A. Laferrere, N. Parson, X. Zhou, G. Thompson, Effect of microstructure on the corrosion behaviour of extruded heat exchanger aluminium alloys, Surf. Interface Anal. 45 (2013) 1597-1603. doi:10.1002/sia.5282.

[21] K.D. Wade, D.H. Scott, Development of improved aluminum vacuum brazing core alloy, Inst. Met. Alum. Technol., Proc. Int. Conf. London, Engl. (1986) 521-527.

[22] D.J. Schmatz, Grain boundary penetration during brazing of aluminum, Weld. Res. Suppl. 10 (1983) 267-271-s.

[23] F.N. Afshar, R. Ambat, C. Kwakernaak, J.H.W. de Wit, J.M.C. Mol, H. Terryn, Electrochemical depth profiling of multilayer metallic structures: An aluminum brazing sheet, Electrochim. Acta. 77 (2012) 285-293. doi:10.1016/j.electacta.2012.06.023.

[24] F.N. Afshar, F.D. Tichelaar, A.M. Glenn, P. Taheri, M. Sababi, H. Terryn, J.M.C. Mol, Improved corrosion resistance of aluminum brazing sheet by a post-brazing heat treatment, Corrosion. 73 (2017) 379-393. doi:10.5006/2210.

[25] F.N. Afshar, J.H.W. De Wit, H. Terryn, J.M.C. Mol, Scanning Kelvin probe force microscopy as a means of predicting the electrochemical characteristics of the surface of a modified AA4xxx/AA3xxx (Al alloys) brazing sheet, Electrochim. Acta. 88 (2013) 330-339. doi:10.1016/j.electacta.2012.10.051.

[26] Q. Shi, F. Liang, B. Cheadle, Electrochemical behaviors of quad-layer aluminum brazing sheet composite for automotive applications, Corrosion. 60 (2004) 492-500.

[27] M.R. Winchester, R. Payling, Radio-frequency glow discharge spectrometry: A critical review, Spectrochim. Acta - Part B At. Spectrosc. 59 (2004) 607-666. 
doi:10.1016/j.sab.2004.02.013.

[28] N. Birbilis, R.G. Buchheit, Electrochemical Characteristics of Intermetallic Phases in Aluminum Alloys: An Experimental Survey and Discussion, J. Electrochem. Soc. 152 (2005) B140-B151. doi:10.1149/1.1869984.

[29] T. Suter, H. Böhni, Microelectrodes for studies of localized corrosion processes, Electrochim. Acta. 43 (1998) 2843-2849. doi:10.1016/S0013-4686(98)00025-5.

[30] T. Suter, H. Böhni, Microelectrodes for corrosion studies in microsystems, Electrochim. Acta. 47 (2001) 191-199. doi:10.1016/S0013-4686(01)00551-5.

[31] M.M. Lohrengel, Electrochemical capillary cells, Corros. Eng. Sci. Technol. 39 (2004) 53-58. doi:10.1179/147842204225016877.

[32] F. Andreatta, M.E. Druart, A. Lanzutti, M. Lekka, D. Cossement, M.G. Olivier, L. Fedrizzi, Localized corrosion inhibition by cerium species on clad AA2024 aluminium alloy investigated by means of electrochemical micro-cell, Corros. Sci. 65 (2012) 376386. doi:10.1016/j.corsci.2012.08.053.

[33] F. Andreatta, M.E. Druart, E. Marin, D. Cossement, M.G. Olivier, L. Fedrizzi, Volta potential of clad AA2024 aluminium after exposure to $\mathrm{CeCl} 3$ solution, Corros. Sci. 86 (2014) 189-201. doi:10.1016/j.corsci.2014.05.008.

[34] J. Lacaze, S. Tierce, M.-C. Lafont, Y. Thebault, N. Pébère, G. Mankowski, C. Blanc, H. Robidou, D. Vaumousse, D. Daloz, Study of the microstructure resulting from brazed aluminum materials used in heat exchangers, Mater. Sci. Eng. A (2005) 317-321. doi:http://dx.doi.org/10.1016/j.msea.2005.08.187.

[35] R. Ambat, P. Møller, Corrosion investigation of material combinations in a mobile phone dome-key pad system, Corros. Sci. $49 \quad$ (2007) 2866-2879. doi:http://dx.doi.org/10.1016/j.corsci.2006.12.013.

[36] M. Jariyaboon, A.J. Davenport, R. Ambat, B.J. Connolly, S.W. Williams, D.A. Price, 
The effect of welding parameters on the corrosion behaviour of friction stir welded AA2024-T351, Corros. Sci. 49 (2007) 877-909. doi:10.1016/j.corsci.2006.05.038.

[37] L. Peguet, V. Lair, E. Mendez, H. Noui, Corrosion mechanisms in aluminium cladded sheets for automotive heat exchangers studied by electrochemical depth profiling, in: Eurocorr, 2016.

[38] L. Peguet, V. Lair, E. Mendez, H. Noui, Development of an electrochemical depth profiling method to optimize the corrosion protection on aluminium cladded sheets for automotive heat exchangers, in: 9th Int. Congr. Exhib. Alum. Brazing, Dusseldorf, 2016.

[39] G69-12, Standard Test Method for Measurement of Corrosion Potentials of Aluminum Alloys, ASTM Int. (2013) 1-5. doi:10.1520/G0069-12.2.

[40] P.C. King, I.S. Cole, P.A. Corrigan, A.E. Hughes, T.H. Muster, FIB/SEM study of AA2024 corrosion under a seawater drop: Part I, Corros. Sci. 53 (2011) 1086-1096. doi:10.1016/j.corsci.2010.12.004.

[41] P.C. King, I.S. Cole, P.A. Corrigan, A.E. Hughes, T.H. Muster, S. Thomas, FIB/SEM study of AA2024 corrosion under a seawater drop, part II, Corros. Sci. 55 (2012) 116125. doi:10.1016/j.corsci.2011.10.012.

[42] V.C. Gudla, K. Rechendorff, Z.I. Balogh, T. Kasama, R. Ambat, In-situ TEM investigation of microstructural evolution in magnetron sputtered $\mathrm{Al}-\mathrm{Zr}$ and $\mathrm{Al}-\mathrm{Zr}-\mathrm{Si}$ coatings during heat treatment, Mater. Des. 89 (2016) 1071-1078. doi:10.1016/j.matdes.2015.10.081.

[43] M. Aggerbeck, A.J. Holst, D. Nielsen, V. Gudla, R. Ambat, Anodisation of Sputter Deposited Aluminium - Titanium Coatings : Effect of Microstructure on Optical Characteristics, Surf. Coatings Technol. $254 \quad$ (2014) 1-10. doi:http://dx.doi.org/10.1016/j.surfcoat.2014.05.073.

[44] V.C. Gudla, F. Jensen, K. Bordo, A. Simar, R. Ambat, Effect of High Frequency Pulsing 
on the Interfacial Structure of Anodized Aluminium-TiO2, J. Electrochem. Soc. 162 (2015) C303-C310. doi:10.1149/2.0311507jes.

[45] K. Fushimi, S. Yamamoto, R. Ozaki, H. Habazaki, Cross-section corrosion-potential profiles of aluminum-alloy brazing sheets observed by the flowing electrolyte scanningdroplet-cell technique, Electrochim. Acta. $53 \quad$ (2008) 2529-2537. doi:10.1016/j.electacta.2007.10.044.

[46] S. Tierce, N. Pébère, C. Blanc, C. Casenave, G. Mankowski, H. Robidou, Corrosion behaviour of brazing material AA4343, Electrochim. Acta. 52 (2006) 1092-1100. doi:10.1016/j.electacta.2006.07.007.

[47] S. Tierce, N. Pébère, C. Blanc, C. Casenave, G. Mankowski, H. Robidou, Corrosion behaviour of brazed multilayer material AA4343/AA3003/AA4343: Influence of coolant parameters, Corros. Sci. 49 (2007) 4581-4593. doi:10.1016/j.corsci.2007.04.013.

[48] M. Dehmas, R. Valdés, M.-C. Lafont, J. Lacaze, B. Viguier, Identification of intermetallic precipitates formed during re-solidification of brazed aluminium alloys, Scr. Mater. 55 (2006) 191-194. doi:http://dx.doi.org/10.1016/j.scriptamat.2006.03.038.

[49] ASM Handbook - Alloy Phase Diagrams - Volume 3, ASM Intermational, 1992.

[50] Y.J. Li, L. Arnberg, Quantitative study on the precipitation behavior of dispersoids in DC-cast AA3003 alloy during heating and homogenization, Acta Mater. 51 (2003) 3415-3428. doi:10.1016/S1359-6454(03)00160-5.

[51] P. Donnadieu, G. Lapasset, T.H. Sanders, Manganese-induced ordering in the $\alpha$-(Al-MnFe-Si) approximant phase, Philos. Mag. Lett. $70 \quad$ (1994) 319-326. doi:10.1080/09500839408240993.

[52] R. Parvizi, A.E. Hughes, M.Y. Tan, R.K.W. Marceau, M. Forsyth, P. Cizek, A.M. Glenn, Probing corrosion initiation at interfacial nanostructures of AA2024-T3, 2017. doi:10.1016/j.corsci.2016.12.006. 
[53] D.T.L. Alexander, A.L. Greer, Solid-state intermetallic phase tranformations in 3XXX aluminium alloys, Acta Mater. 50 (2002) 2571-2583. doi:10.1016/S13596454(02)00085-X.

[54] K. Liu, X.G. Chen, Evolution of Intermetallics, Dispersoids, and Elevated Temperature Properties at Various Fe Contents in Al-Mn-Mg 3004 Alloys, Metall. Mater. Trans. B Process Metall. Mater. Process. Sci. 47 (2016) 3291-3300. doi:10.1007/s11663-0150564-y.

[55] F. Norouzi Afshar, J.H.W. de Wit, H. Terryn, J.M.C. Mol, The effect of brazing process on microstructure evolution and corrosion performance of a modified AA4XXX/AA3XXX brazing sheet, Corros. Sci. 58 (2012) 242-250. doi:10.1016/j.corsci.2012.01.030.

[56] X. Zhang, T. Hashimoto, J. Lindsay, X. Zhou, Investigation of the de-alloying behaviour of $\theta$-phase (A12Cu) in AA2024-T351 aluminium alloy, Corros. Sci. 108 (2016) 85-93. doi:10.1016/j.corsci.2016.03.003.

[57] N. Birbilis, Y.M. Zhu, S.K. Kairy, M.A. Glenn, J.F. Nie, A.J. Morton, Y. GonzalezGarcia, H. Terryn, J.M.C. Mol, A.E. Hughes, A closer look at constituent induced localised corrosion in Al-Cu-Mg alloys, Corros. Sci. 113 (2016) 160-171. doi:10.1016/j.corsci.2016.10.018.

[58] J. Wang, B. Zhang, B. Wu, X.L. Ma, Size-dependent role of S phase in pitting initiation of 2024Al alloy, Corros. Sci. 105 (2016) 183-189. doi:10.1016/j.corsci.2016.01.016.

[59] C. Vargel, M. Jacques, M.P. Schmidt, Chapter B.1 - The Corrosion of Aluminium, in: C.V.J.P.B.T.-C. of A. Schmidt (Ed.), Corros. Alum., Elsevier, Amsterdam, 2004: pp. 81-109. doi:http://dx.doi.org/10.1016/B978-008044495-6/50011-2.

[60] Z. Szklarska-Smialowska, Pitting corrosion of aluminum, Corros. Sci. 41 (1999) 17431767. doi:10.1016/S0010-938X(99)00012-8. 
[61] Z. Wang, P. Chen, H. Li, B. Fang, R. Song, Z. Zheng, The intergranular corrosion susceptibility of $2024 \mathrm{Al}$ alloy during re-ageing after solution treating and cold-rolling, Corros. Sci. 114 (2017) 156-168. doi:10.1016/j.corsci.2016.11.013.

[62] M. Esmaily, N. Mortazavi, W. Osikowicz, H. Hindsefelt, J.E. Svensson, M. Halvarsson, G.E. Thompson, L.G. Johansson, Corrosion behaviour of friction stir-welded AA6005T6 using a bobbin tool, Corros. Sci. 111 (2016) 98-109. doi:10.1016/j.corsci.2016.04.046.

[63] J. Li, N. Birbilis, R.G. Buchheit, Electrochemical assessment of interfacial characteristics of intermetallic phases present in aluminium alloy 2024-T3, Corros. Sci. 101 (2015) 155-164. doi:10.1016/j.corsci.2015.09.012.

[64] S.R.K. Malladi, F.D. Tichelaar, Q. Xu, M.Y. Wu, H. Terryn, J.M.C. Mol, F. Hannour, H.W. Zandbergen, Quasi in situ analytical TEM to investigate electrochemically induced microstructural changes in alloys: AA2024-T3 as an example, Corros. Sci. 69 (2013) 221-225. doi:10.1016/j.corsci.2012.12.006.

[65] A. Davoodi, J. Pan, C. Leygraf, S. Norgren, Multianalytical and In Situ Studies of Localized Corrosion of EN AW-3003 Alloy-Influence of Intermetallic Particles, J. Electrochem. Soc. 155 (2008) C138. doi:10.1149/1.2834454.

[66] A. Davoodi, J. Pan, C. Leygraf, S. Norgren, The Role of Intermetallic Particles in Localized Corrosion of an Aluminum Alloy Studied by SKPFM and Integrated AFM/SECM, J. Electrochem. Soc. 155 (2008) C211. doi:10.1149/1.2883737.

[67] A. Davoodi, J. Pan, C. Leygraf, R. Parvizi, S. Norgren, An insight into the influence of morphological and compositional heterogeneity of an individual intermetallic particle on aluminium alloy corrosion initiation, Mater. Corros. 64 (2013) 195-198. doi:10.1002/maco.201106466. 


\section{$\underline{\text { List of Figures }}$}

Figure 1: Schematic cross-section of multiclad Al brazing sheet showing the different alloy types and their relative thicknesses used in this study. The relative thicknesses are not to scale.

Figure 2: Localized electrochemical cell setup used for performing the potentiodynamic polarization studies.

Figure 3: GDOES elemental profiles of $\mathrm{Si}, \mathrm{Mn} \mathrm{Fe}$ and $\mathrm{Cu}$ in the (a) Reference and (b) Multiclad sheets in as rolled (AR) and brazed (BZ) condition.

Figure 4: SEM back scattered cross section images of multiclad sheet with AA3xxx interlayer in (a), (b) as rolled, and (c), (d) brazed condition; and reference sample in (e) as rolled and (f) brazed condition.

Figure 5: Bright field TEM images of the interfaces between the (a), (c) AA4343 clad and AA3003 interlayer and (b), (d) AA3xxx interlayer and AA3xxx core in as rolled condition and brazed condition respectively.

Figure 6: Potentiodynamic anodic polarization scans obtained in $0.1 \mathrm{M} \mathrm{HCl}$ solution for the (a) Reference and (b) Multiclad sheets in as rolled and brazed condition.

Figure 7: Ecorr values obtained from the potentiodynamic polarization measurements for the various layers of reference and multiclad sheets in as rolled and brazed conditions. Potentials are measured vs. an $\mathrm{Ag} / \mathrm{AgCl}$ reference electrode, scan rate was $1 \mathrm{mV} / \mathrm{s}$.

Figure 8: Figure 8: Evolution of galvanic current density and galvanic potential vs. time obtained from the ZRA measurements for the AA4343 clad (WE1) coupled with AA3xxx interlayer (WE2); and AA3xxx interlayer (WE1) coupled with AA3xxx core (WE2) in (a) as rolled, and (b) brazed condition measured in $0.1 \mathrm{M} \mathrm{NaCl}$ solution with $\mathrm{pH}$ 2.8. In the as rolled condition, positive current density is measured flowing from WE2 to WE1 (AA3xxx interlayer to AA4343 clad; and AA3xxx core to AA3xxx interlayer), suggesting WE1 is anodic to WE2. In brazed condition, no clear direction of current density flow is observed. 
(a) Multiclad

\begin{tabular}{|c|}
\hline $\begin{array}{c}\text { AA4343 }-36 ~ \mu \mathrm{m} \\
\text { (Clad) }\end{array}$ \\
\hline $\begin{array}{c}\text { AA3xxx Low Cu }-38 \mu \mathrm{m} \\
\text { (Interlayer) }\end{array}$ \\
\hline $\begin{array}{c}\text { Modified AA3xxx } \\
\text { (Core) }\end{array}$ \\
\hline
\end{tabular}

(b) Reference

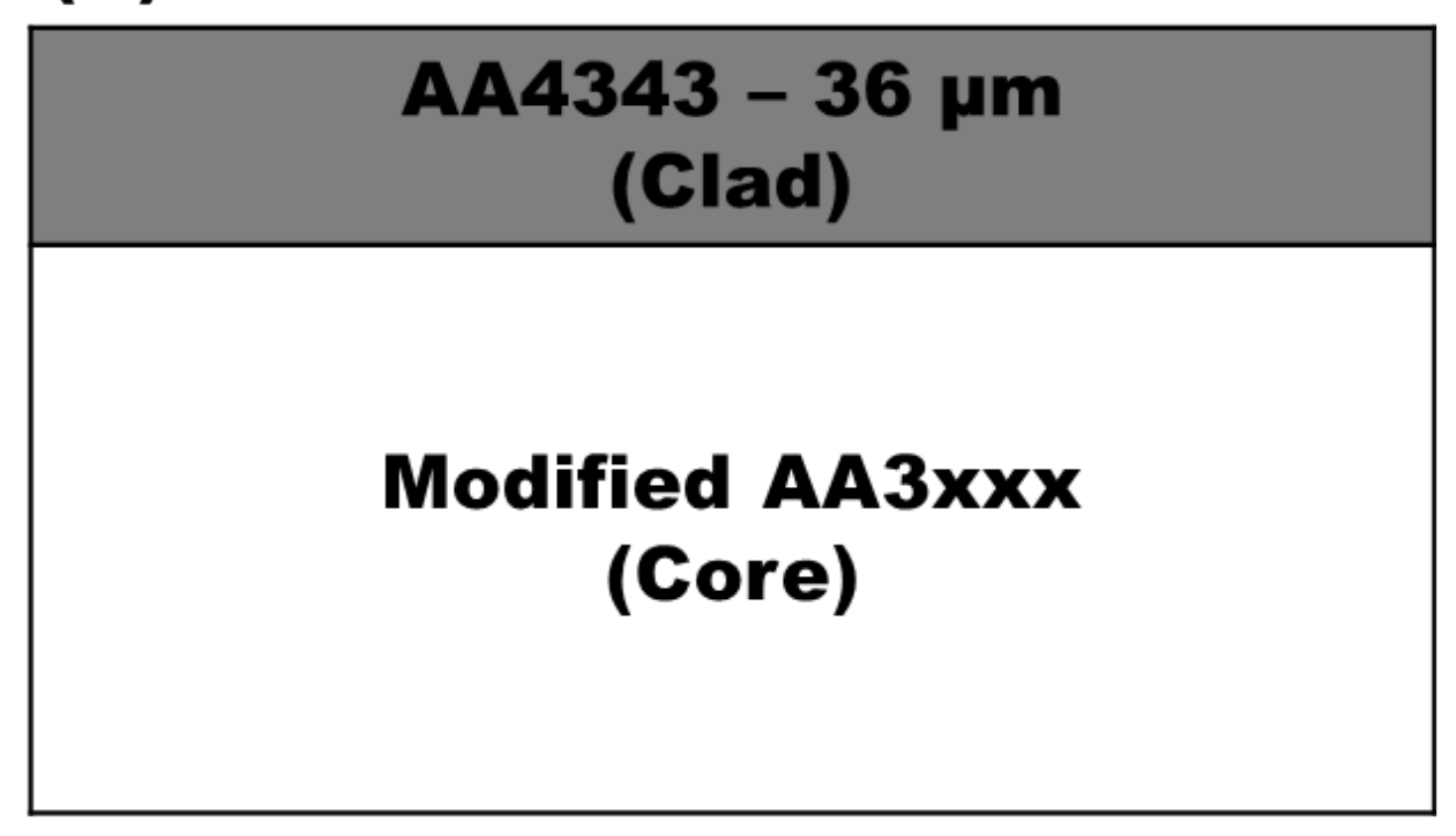

Figure 1: Schematic cross-section of (a) Multiclad and (b)Reference Aluminium brazing sheets used in this study. The relative thicknesses are not to scale. 


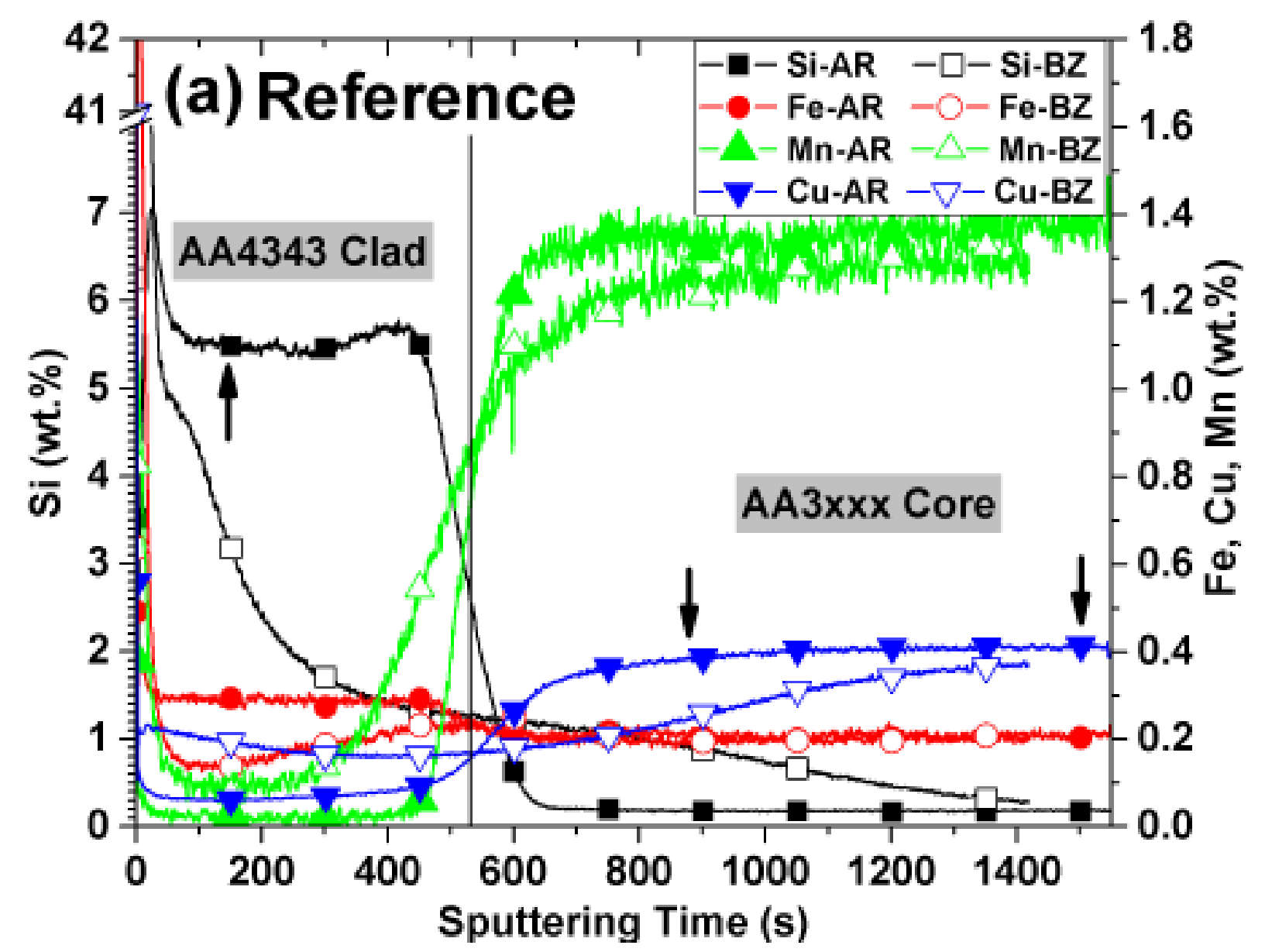

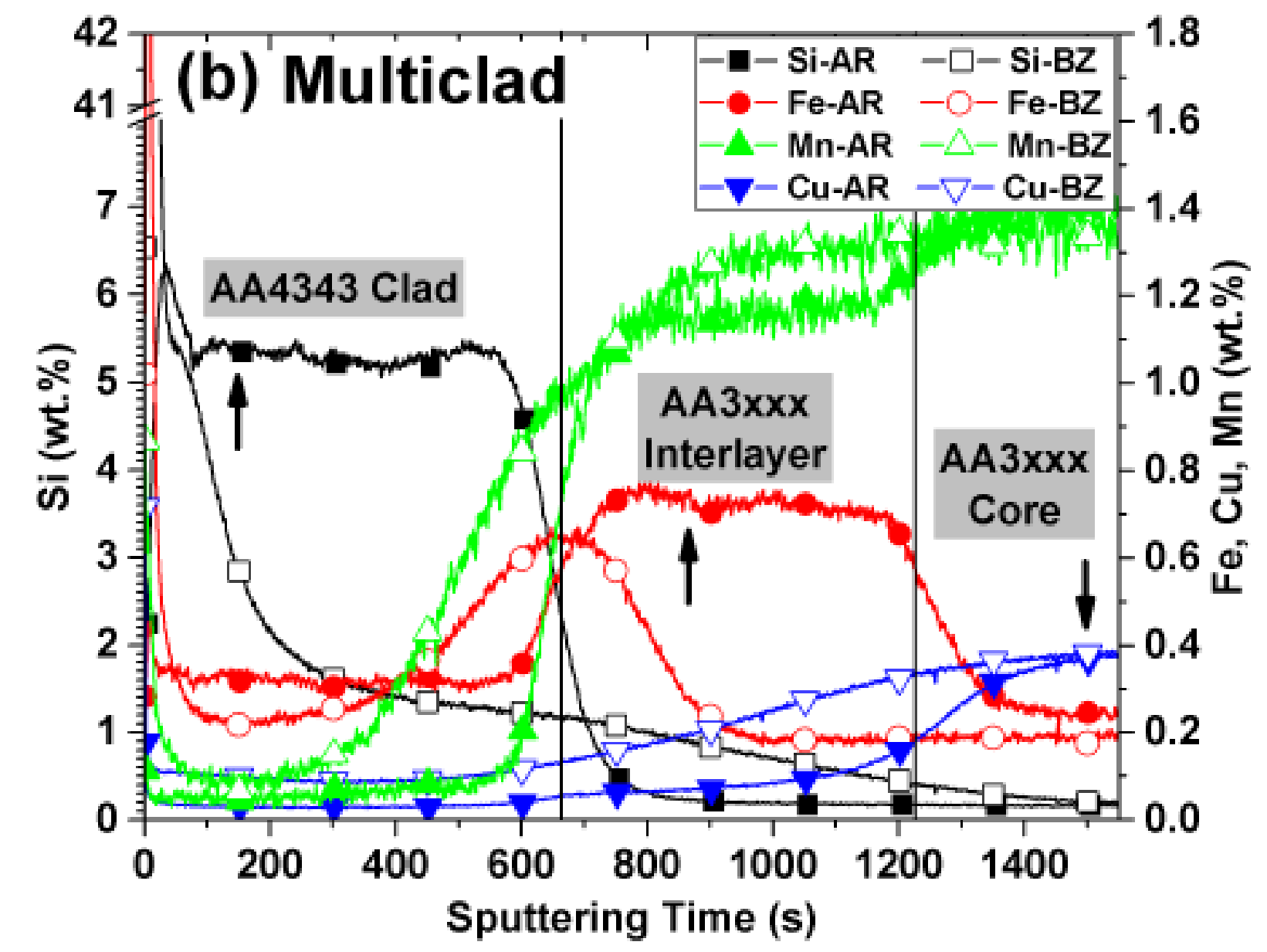

Figure 3: GDOES elemental profiles of $\mathrm{Si}, \mathrm{Mn}, \mathrm{Fe}$, and $\mathrm{Cu}$ in the (a) Reference and (b) Multiclad sheets in as rolled (AR) and brazed (BZ) condition. 


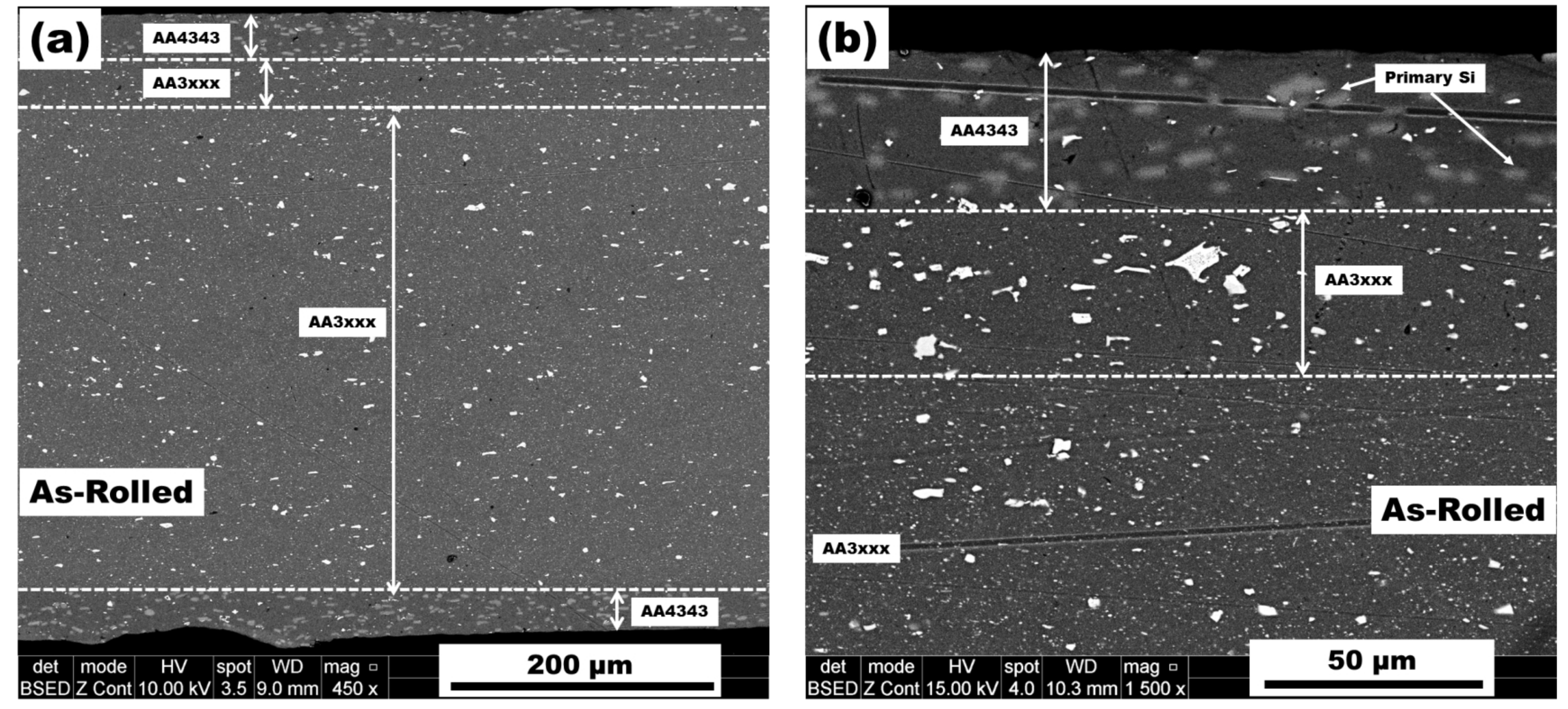

Figure 4: SEM back scattered cross section images of multiclad sheet with AA3xxx interlayer in (a), (b) as rolled, and (c), (d) brazed condition; and reference sample in (e) as rolled and (f) brazed condition. 


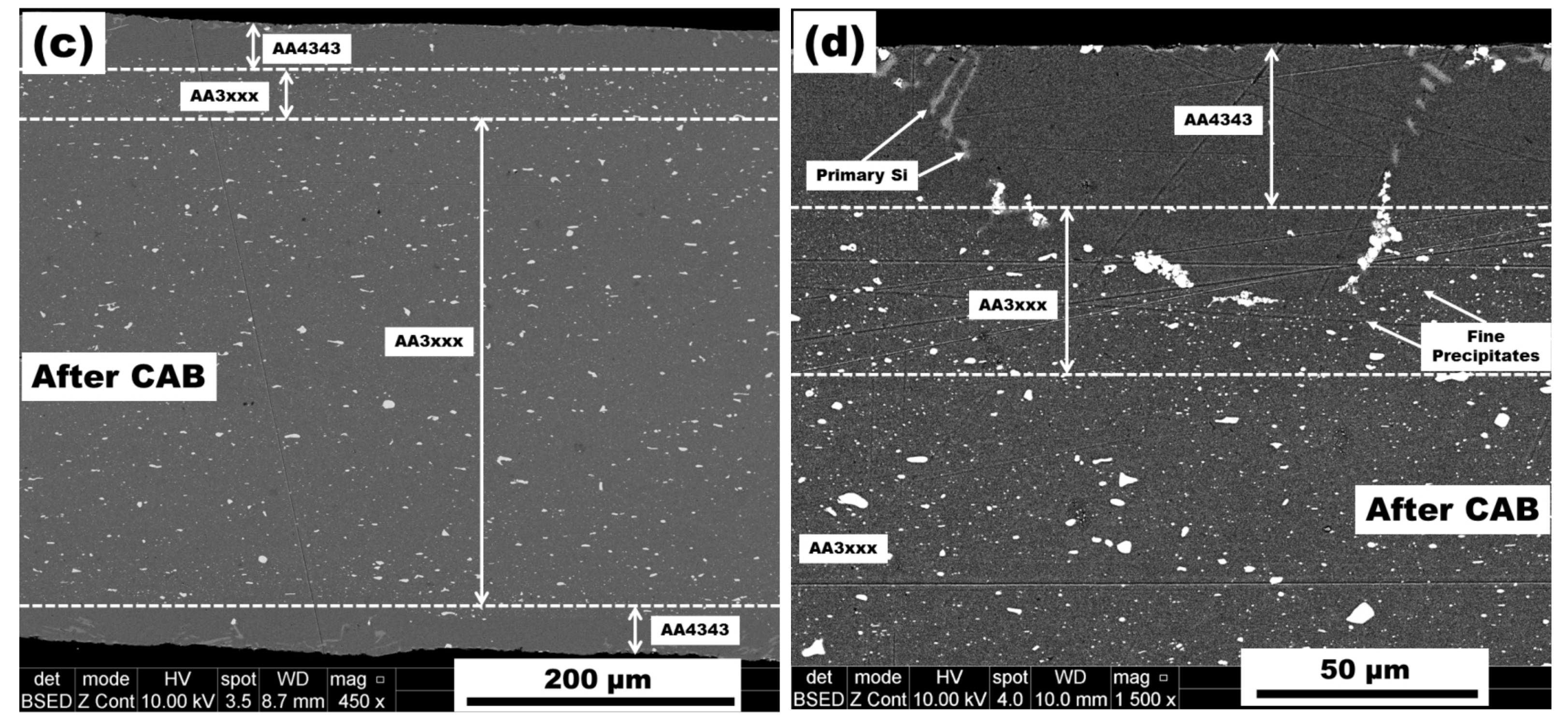

Figure 4: SEM back scattered cross section images of multiclad sheet with AA3xxx interlayer in (a), (b) as rolled, and (c), (d) brazed condition; and reference sample in (e) as rolled and (f) brazed condition. 

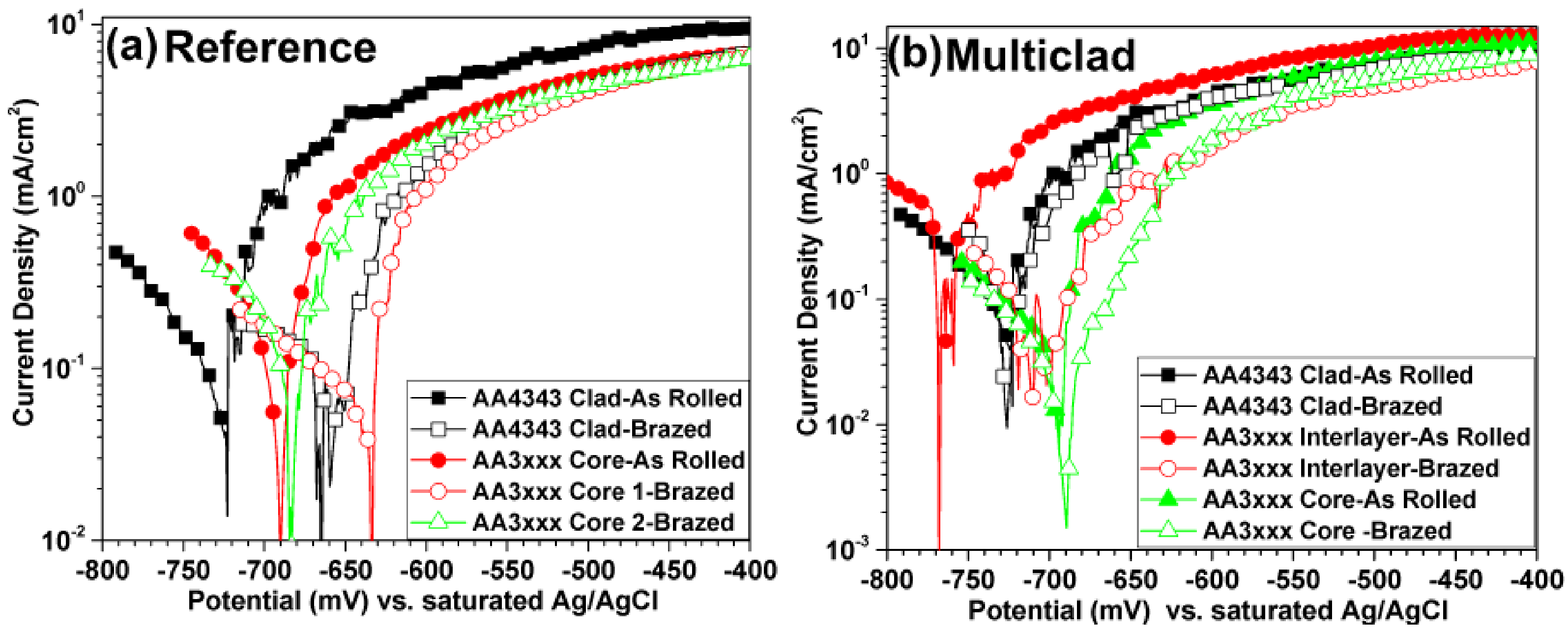

Figure 6: Potentiodynamic anodic polarization scans obtained in $0.1 \mathrm{M} \mathrm{HCl}$ solution for the (a) Reference and (b) Multiclad sheets in as rolled and brazed condition. 


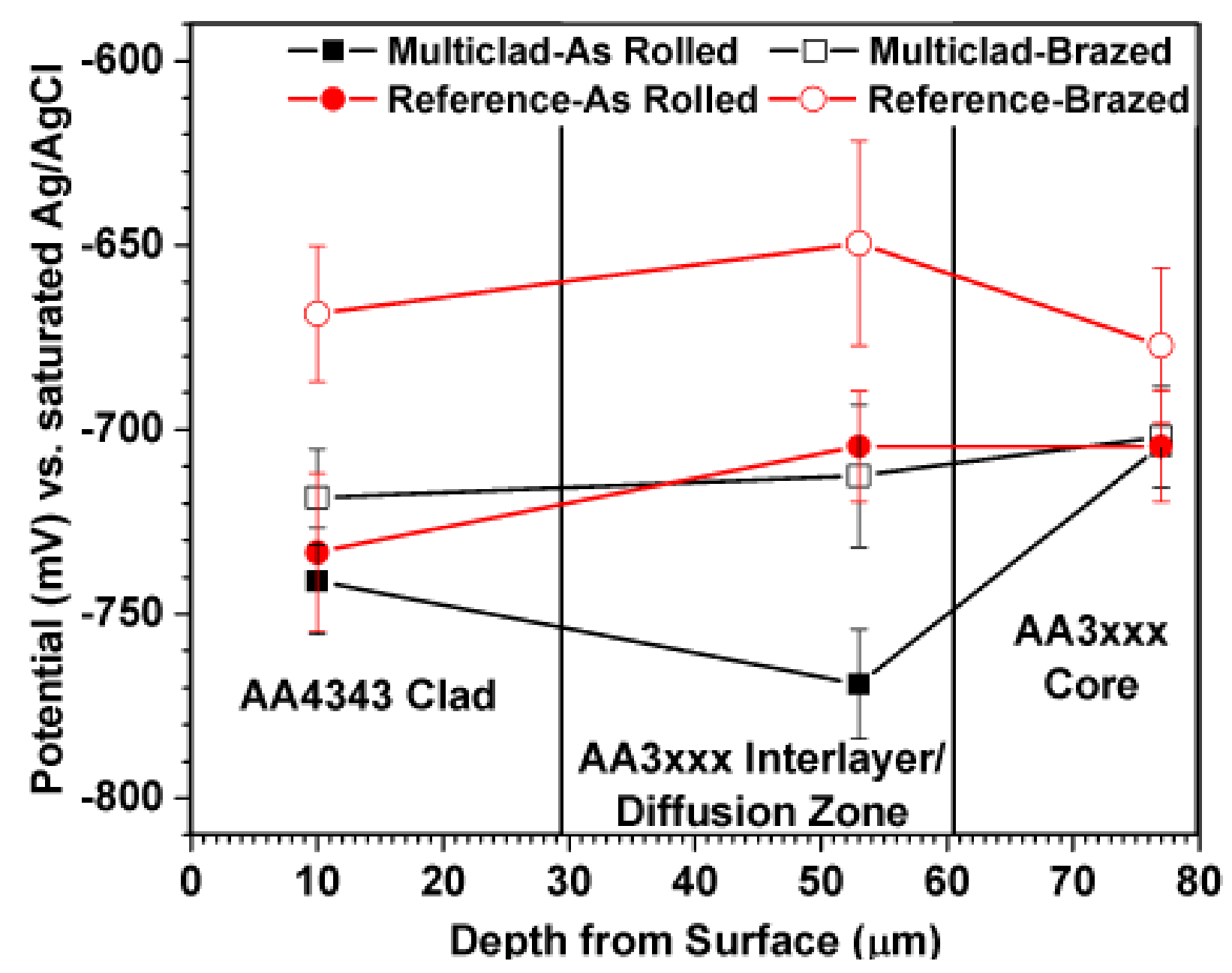

Figure 7: $\mathrm{E}_{\text {corr }}$ values obtained from the potentiodynamic polarization measurements for the various layers of reference and multiclad sheets in as rolled and brazed conditions. Potentials are measured vs. an $\mathrm{Ag} / \mathrm{AgCl}$ reference electrode, scan rate was $1 \mathrm{mV} / \mathrm{s}$. 

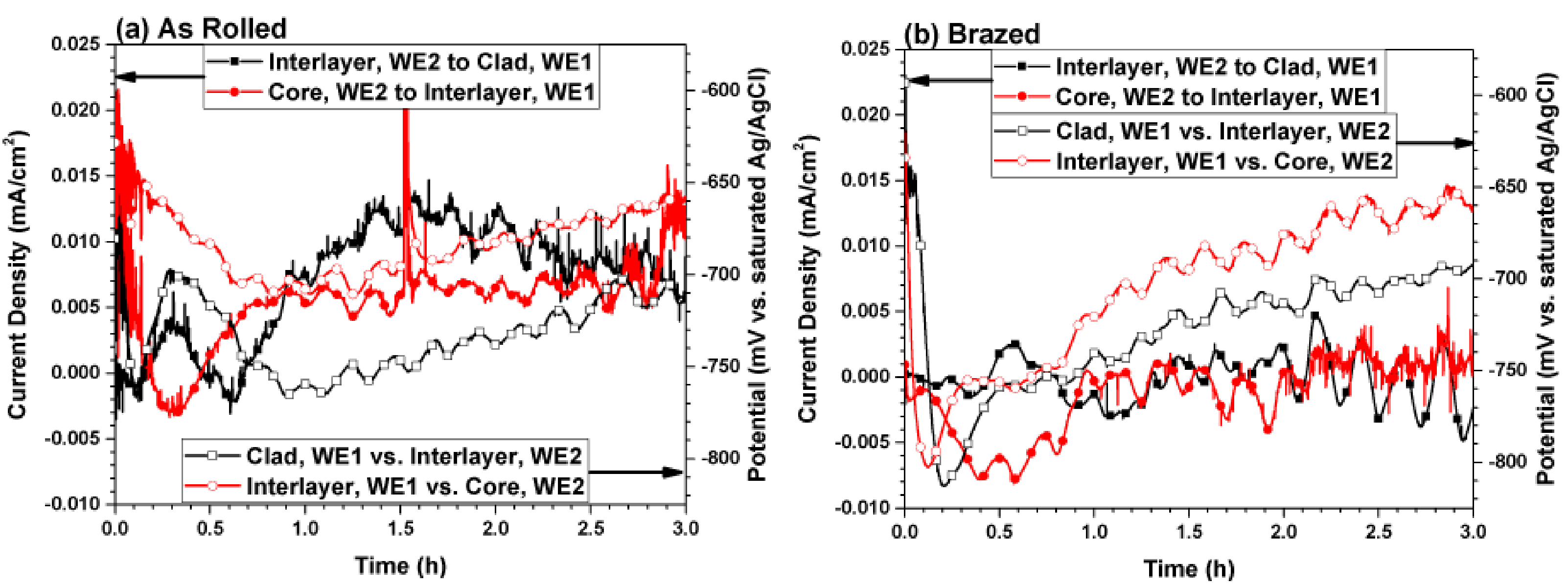

Figure 8: Evolution of galvanic current density and galvanic potential vs. time obtained from the ZRA measurements for the AA4343 clad (WE1) coupled with AA3xxx interlayer (WE2); and AA3xxx interlayer (WE1) coupled with AA3xxx core (WE2) in (a) as rolled, and (b) brazed condition measured in $0.1 \mathrm{M} \mathrm{NaCl}$ solution with $\mathrm{pH} 2.8$. In the as rolled condition, positive current density is measured flowing from WE2 to WE1 (AA3xxx interlayer to AA4343 clad; and AA3xxx core to AA3xxx interlayer), suggesting WE1 is anodic to WE2. In brazed condition, no clear direction of current density flow is observed. 


\section{$\underline{\text { List of Tables }}$}

Table 1: Composition of the materials (in wt.\%) used in the Aluminium brazing sheets.

Table 2: Representative elemental composition analysis (in wt.\%) measured by RF-GDOES at different sputter depths of the multiclad and reference sheets in as rolled and brazed condition.

Table 3: Representative elemental composition analysis (in at.\%) measured by EDS (TEM) of the individual features of the multiclad sheets in as rolled and brazed condition. 
Table 1: Composition of the materials (in wt.\%) used in the Aluminium brazing sheets.

\begin{tabular}{|c|c|c|c|c|c|c|c|c|c|c|}
\hline & $\mathbf{S i}$ & $\mathbf{F e}$ & $\mathbf{C u}$ & $\mathbf{M n}$ & $\mathbf{M g}$ & $\mathbf{C r}$ & $\mathbf{N i}$ & $\mathbf{Z n}$ & $\mathbf{T i}$ & $\mathbf{A l}$ \\
\hline $\mathbf{A A 4 3 4 3}$ & 7.2 & 0.3 & 0.1 & 0.1 & 0.0035 & 0.05 & 0.03 & 0.05 & 0.05 & Bal. \\
\hline AA3xxx Interlayer & 0.22 & 0.57 & 0.08 & 1.15 & 0.02 & 0.05 & 0.03 & 0.1 & 0.05 & Bal. \\
\hline AA3xxx Core & 0.2 & 0.2 & 0.65 & 1.35 & 0.02 & 0.05 & 0.05 & 0.1 & 0.08 & Bal. \\
\hline
\end{tabular}


Table 2: Representative elemental composition analysis (in wt.\%) measured by RF-GDOES at different sputter depths of the multiclad and reference sheets in as rolled and brazed condition.

\begin{tabular}{|c|c|c|c|c|c|c|c|c|}
\hline \multicolumn{2}{|c|}{ Condition } & Material & Al & Si & $\mathbf{F e}$ & $\mathrm{Cu}$ & Mn & $\begin{array}{c}\text { Others } \\
(\mathrm{Cr}, \mathrm{Zn}, \mathrm{Ti}, \mathrm{Mg}, \mathrm{Ni} \\
\text { \& O) }\end{array}$ \\
\hline \multirow{3}{*}{\multicolumn{2}{|c|}{$\begin{array}{l}\frac{\bar{\omega}}{\overline{0}} \\
\frac{\pi}{4} \\
\frac{u}{4}\end{array}$}} & $\begin{array}{c}\text { AA4343 } \\
\text { Clad } \\
\end{array}$ & $92.4 \pm 0.7$ & $5.3 \pm 0.1$ & $0.3 \pm 0.1$ & 0.03 & 0.06 & 1.7 \\
\hline & & $\begin{array}{c}\text { AA3xxx } \\
\text { Interlayer }\end{array}$ & $96.3 \pm 0.6$ & $0.2 \pm 0.1$ & $0.7 \pm 0.1$ & 0.1 & $1.1 \pm 0.1$ & 1.5 \\
\hline & & $\begin{array}{c}\text { AA3xxx } \\
\text { Core }\end{array}$ & $96.2 \pm 0.4$ & $0.2 \pm 0.1$ & $0.3 \pm 0.1$ & $0.4 \pm 0.1$ & $1.4 \pm 0.3$ & 1.5 \\
\hline \multirow{6}{*}{ 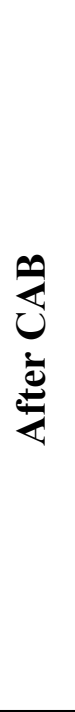 } & \multirow{3}{*}{ 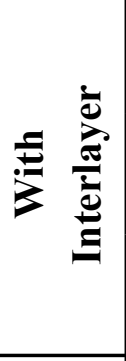 } & $\begin{array}{c}\text { AA4343 } \\
\text { Clad }\end{array}$ & $96.7 \pm 0.5$ & $2.1 \pm 0.2$ & 0.2 & 0.1 & 0.1 & 0.7 \\
\hline & & $\begin{array}{c}\text { AA3xxx } \\
\text { Interlayer } \\
\end{array}$ & $96.5 \pm 0.4$ & $0.9 \pm 0.1$ & $0.3 \pm 0.1$ & 0.2 & $1.2 \pm 0.1$ & 0.8 \\
\hline & & $\begin{array}{c}\text { AA3xxx } \\
\text { Core }\end{array}$ & $96.9 \pm 0.4$ & $0.3 \pm 0.1$ & 0.2 & $0.4 \pm 0.1$ & $1.3 \pm 0.1$ & 0.8 \\
\hline & \multirow{3}{*}{ 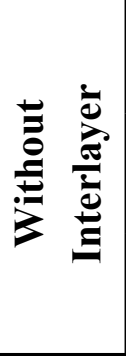 } & $\begin{array}{c}\text { AA4343 } \\
\text { Clad }\end{array}$ & $96.5 \pm 0.4$ & $2.3 \pm 0.1$ & 0.2 & 0.2 & 0.1 & 0.6 \\
\hline & & $\begin{array}{l}\text { AA3xxx } \\
\text { Core - 1 } \\
\end{array}$ & $96.6 \pm 0.3$ & $0.9 \pm 0.1$ & 0.2 & 0.3 & $1.3 \pm 0.1$ & 0.7 \\
\hline & & $\begin{array}{l}\text { AA3xxx } \\
\text { Core -2 }\end{array}$ & $95.2 \pm 0.8$ & $0.3 \pm 0.1$ & 0.2 & $0.4 \pm 0.1$ & $1.3 \pm 0.1$ & 2.5 \\
\hline
\end{tabular}




\section{Table 3: Representative elemental composition analysis (in at.\%) measured by EDS (TEM) of the individual}

features of the multiclad sheets in as rolled, and brazed condition.

\begin{tabular}{|c|c|c|c|c|c|c|c|c|c|c|c|}
\hline \multicolumn{2}{|c|}{ Material } & Feature & Al & Si & Mn & $\mathbf{F e}$ & $\mathbf{C u}$ & $\mathbf{T i}$ & $\mathbf{V}$ & $\mathrm{Cr}$ & Proposed Phase \\
\hline \multirow{13}{*}{ 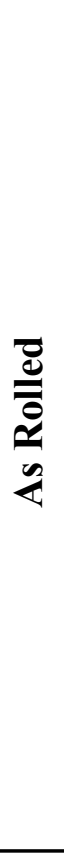 } & 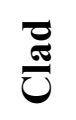 & Primary Si & $1.1 \pm 0.17$ & $98.9 \pm 0.17$ & & & & & & & $\mathrm{Si}$ \\
\hline & \multirow{6}{*}{ 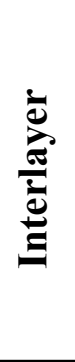 } & Dispersoid & $88.66 \pm 0.29$ & $3.51 \pm 0.11$ & $7.18 \pm 0.15$ & $0.66 \pm 0.06$ & & & & & $\mathrm{Al}_{15}(\mathrm{Fe}, \mathrm{Mn})_{3} \mathrm{Si}_{1-2} ; \mathrm{Fe}+\mathrm{Mn}: \mathrm{Si}=2.23$ \\
\hline & & Dispersoid & $89.8 \pm 0.23$ & & $5.3 \pm 0.11$ & $4.9 \pm 0.33$ & & & & & $\mathrm{Al}_{6}(\mathrm{Mn}, \mathrm{Fe})$ \\
\hline & & Dispersoid & $85.8 \pm 1.49$ & $5.24 \pm 0.58$ & $8.96 \pm 0.91$ & & & & & & $\alpha-\mathrm{AlMnSi} ;\left(\tau_{9}\right)\left(\mathrm{Al}_{9} \mathrm{Mn}_{2} \mathrm{Si}\right)$ \\
\hline & & Constituent Particle & $78.05 \pm 0.3$ & $7.52 \pm 0.08$ & $5.84 \pm 0.86$ & $8.59 \pm 1.06$ & & & & & $\mathrm{Al}_{15}(\mathrm{Fe}, \mathrm{Mn})_{3} \mathrm{Si}_{1-2} ; \mathrm{Fe}+\mathrm{Mn}: \mathrm{Si}=1.92$ \\
\hline & & Constituent Particle & $80.24 \pm 2.88$ & $6.2 \pm 0.56$ & $6.04 \pm 0.56$ & $7.52 \pm 1.76$ & & & & & $\mathrm{Al}_{15}(\mathrm{Fe}, \mathrm{Mn})_{3} \mathrm{Si}_{1-2} ; \mathrm{Fe}+\mathrm{Mn}: \mathrm{Si}=2.19$ \\
\hline & & Constituent Particle & $85.32 \pm 0.02$ & & $6.74 \pm 0.13$ & $7.95 \pm 0.13$ & & & & & $\mathrm{Al}_{6}(\mathrm{Mn}, \mathrm{Fe})$ \\
\hline & \multirow{6}{*}{ 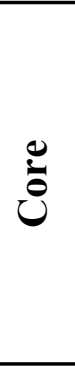 } & Constituent Particle & $77.58 \pm 0.23$ & $4.09 \pm 0.03$ & $12.27 \pm 0.13$ & $6.06 \pm 0.34$ & & & & & $\alpha-\mathrm{Al}(\mathrm{Fe}, \mathrm{Mn}) \mathrm{Si}$ \\
\hline & & Constituent Particle & $77.56 \pm 0.05$ & $6.11 \pm 0.04$ & $13.28 \pm 0.06$ & $3.05 \pm 0.07$ & & & & & $\mathrm{Al}_{15}(\mathrm{Fe}, \mathrm{Mn})_{3} \mathrm{Si}_{1-2} ; \mathrm{Fe}+\mathrm{Mn}: \mathrm{Si}=2.67$ \\
\hline & & Dispersoid & $89.17 \pm 1.33$ & & $10.83 \pm 1.33$ & & & & & & $\mathrm{Al}_{6}(\mathrm{Mn})$ \\
\hline & & Dispersoid & $90.95 \pm 1.09$ & $2.59 \pm 0.28$ & $3.27 \pm 0.39$ & $2.95 \pm 0.42$ & $0.24 \pm 0.01$ & & & & $\mathrm{Al}_{12}(\mathrm{Fe}, \mathrm{Mn}, \mathrm{Cu})_{3} \mathrm{Si}_{1.2-2} ; \mathrm{Fe}+\mathrm{Mn}+\mathrm{Cu}: \mathrm{Si}=2.49$ \\
\hline & & Dispersoid & $88.71 \pm 0.68$ & & $8.76 \pm 0.57$ & & \begin{tabular}{|l|}
0.94 \\
\end{tabular} & $1.4 \pm 0.09$ & $0.19 \pm 0.02$ & & $\mathrm{Al}_{6}(\mathrm{Mn}, \mathrm{Cu})$ \\
\hline & & Dispersoid & $85.2 \pm 1.54$ & $4.31 \pm 0.42$ & $10.43 \pm 1.14$ & & & $0.06 \pm 0.01$ & & & $\alpha-\mathrm{AlMnSi} ;\left(\tau_{9}\right)\left(\mathrm{Al}_{9} \mathrm{Mn}_{2} \mathrm{Si}\right)$ \\
\hline \multirow{18}{*}{ 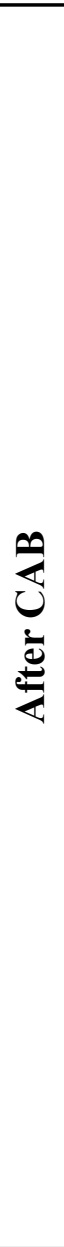 } & $\underset{\bar{T}}{\tilde{U}}$ & Primary Si & $2.04 \pm 0.19$ & $97.96 \pm 0.19$ & & & & & & & $\mathrm{Si}$ \\
\hline & \multirow{4}{*}{ 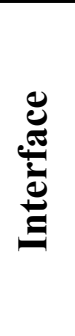 } & Constituent Particle & $73.67 \pm 0.58$ & $10.95 \pm 0.29$ & $8.31 \pm 0.73$ & $6.54 \pm 0.39$ & $0.36 \pm 0.02$ & & $0.13 \pm 0.01$ & $0.05 \pm 0.01$ & $\mathrm{Al}_{32}(\mathrm{Fe}, \mathrm{Mn})_{8}(\mathrm{Al}, \mathrm{Si})_{4} \mathrm{Si}_{2}$ \\
\hline & & Constituent Particle & $72.7 \pm 0.5$ & $10.2 \pm 0.26$ & $7.8 \pm 0.14$ & $8.75 \pm 0.2$ & $0.34 \pm 0.02$ & & $0.14 \pm 0.08$ & $0.07 \pm 0.03$ & $\mathrm{Al}_{12}(\mathrm{Fe}, \mathrm{Mn}, \mathrm{Cu})_{3} \mathrm{Si}_{1.2-2} ; \mathrm{Fe}+\mathrm{Mn}+\mathrm{Cu}: \mathrm{Si}=1.66$ \\
\hline & & \begin{tabular}{|c|}
$\begin{array}{c}\text { Dispersoids-Dense } \\
\text { Precipitates }\end{array}$ \\
\end{tabular} & $75.1 \pm 2.6$ & $9.2 \pm 0.2$ & $6.4 \pm 0.1$ & $7.9 \pm 0.2$ & $1.4 \pm 0.1$ & & & & $\mathrm{Al}_{12}(\mathrm{Fe}, \mathrm{Mn}, \mathrm{Cu})_{3} \mathrm{Si}_{1.2-2} ; \mathrm{Fe}+\mathrm{Mn}+\mathrm{Cu}: \mathrm{Si}=1.71$ \\
\hline & & \begin{tabular}{|c|}
$\begin{array}{c}\text { Dispersoids-Dense } \\
\text { Precipitates }\end{array}$ \\
\end{tabular} & $84.9 \pm 3.7$ & $6.4 \pm 1.1$ & $6.8 \pm 0.8$ & $1.1 \pm 0.1$ & $0.8 \pm 0.1$ & & & & $\mathrm{Al}_{32}(\mathrm{Fe}, \mathrm{Mn})_{8}(\mathrm{Al}, \mathrm{Si})_{4} \mathrm{Si}_{2}$ \\
\hline & \multirow{8}{*}{ 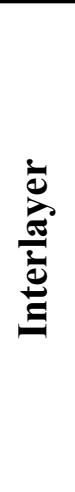 } & Constituent Particle & $73.13 \pm 0.12$ & $10.32 \pm 0.1$ & $7.78 \pm 0.1$ & $8.42 \pm 0.24$ & & & $0.22 \pm 0.02$ & $0.12 \pm 0.01$ & $\mathrm{Al}_{12}(\mathrm{Fe}, \mathrm{Mn})_{3} \mathrm{Si}_{1.2-2}, \mathrm{Fe}+\mathrm{Mn}: \mathrm{Si}=1.57$ \\
\hline & & Constituent Particle & $71.95 \pm 0.03$ & $11.47 \pm 0.07$ & $8.94 \pm 0.29$ & $7.17 \pm 0.27$ & $0.26 \pm 0.01$ & & $0.12 \pm 0.04$ & $0.07 \pm 0.03$ & $\mathrm{Al}_{12}(\mathrm{Fe}, \mathrm{Mn}, \mathrm{Cu})_{3} \mathrm{Si}_{1.2-2}, \mathrm{Fe}+\mathrm{Mn}+\mathrm{Cu}: \mathrm{Si}=1.43$ \\
\hline & & Constituent Particle & $72.69 \pm 0.07$ & $9.25 \pm 0.07$ & $5.31 \pm 0.13$ & $12.05 \pm 0.13$ & $0.7 \pm 0.01$ & & & & $\mathrm{Al}_{12}(\mathrm{Fe}, \mathrm{Mn}, \mathrm{Cu})_{3} \mathrm{Si}_{1.2-2}, \mathrm{Fe}+\mathrm{Mn}+\mathrm{Cu}: \mathrm{Si}=1.95$ \\
\hline & & Constituent Particle & $73.47 \pm 0.06$ & $9.66 \pm 0.1$ & $11.74 \pm 0.83$ & $5.13 \pm 0.76$ & & & & & $\mathrm{Al}_{12}(\mathrm{Fe}, \mathrm{Mn})_{3} \mathrm{Si}_{1.2-2}, \mathrm{Fe}+\mathrm{Mn}: \mathrm{Si}=1.75$ \\
\hline & & Constituent Particle & $73.10 \pm 0.2$ & $10.34 \pm 0.04$ & $14.77 \pm 0.27$ & $1.78 \pm 0.13$ & & & & & $\mathrm{Al}_{12}(\mathrm{Fe}, \mathrm{Mn})_{3} \mathrm{Si}_{1.2-2}, \mathrm{Fe}+\mathrm{Mn}: \mathrm{Si}=1.6$ \\
\hline & & Dispersoid & $90.39 \pm 2.34$ & $4.86 \pm 1.07$ & $4.14 \pm 1.12$ & $0.5 \pm 0.13$ & $0.11 \pm 0.02$ & & & & $\alpha$-AlMnSi; $\left(\tau_{9}\right)\left(\mathrm{Al}_{9} \mathrm{Mn}_{2} \mathrm{Si}\right)$ \\
\hline & & Dispersoid & $84.35 \pm 0.1$ & $7.24 \pm 0.05$ & $8.41 \pm 0.05$ & & & & & & $\alpha-\mathrm{AlMnSi} ;\left(\tau_{9}\right)\left(\mathrm{Al}_{9} \mathrm{Mn}_{2} \mathrm{Si}\right)$ \\
\hline & & Dispersoid & $95.55 \pm 0.27$ & & $4.45 \pm 0.27$ & & & & & & $\mathrm{Al}_{6} \mathrm{Mn}$ \\
\hline & \multirow{5}{*}{ 巳ँ̀ } & Constituent Particle & $74.09 \pm 0.24$ & $9.57 \pm 0.27$ & $12.3 \pm 0.44$ & $4.03 \pm 0.47$ & & & & & $\mathrm{Al}_{12}(\mathrm{Fe}, \mathrm{Mn})_{3} \mathrm{Si}_{1.2-2}, \mathrm{Fe}+\mathrm{Mn}: \mathrm{Si}=1.71$ \\
\hline & & Constituent Particle & $85.07 \pm 0.05$ & $1.17 \pm 0.01$ & $12.54 \pm 0.06$ & $1.22 \pm 0.1$ & & & & & $\mathrm{Al}_{6}(\mathrm{Fe}, \mathrm{Mn}) \mathrm{Si}$ \\
\hline & & Dispersoid & $89.53 \pm 2.66$ & $4.48 \pm 1.14$ & $5.76 \pm 1.43$ & $0.24 \pm 0.09$ & & & & & $\mathrm{Al}_{32}(\mathrm{Fe}, \mathrm{Mn})_{8}(\mathrm{Al}, \mathrm{Si})_{4} \mathrm{Si}_{2}$ \\
\hline & & Dispersoid & $90.67 \pm 0.71$ & $3.87 \pm 0.29$ & $4.88 \pm 0.4$ & $0.23 \pm 0.01$ & $0.18 \pm 0.01$ & $0.17 \pm 0.01$ & & & $\mathrm{Al}_{12}(\mathrm{Fe}, \mathrm{Mn}, \mathrm{Cu})_{3} \mathrm{Si}_{1.2-2}, \mathrm{Fe}+\mathrm{Mn}+\mathrm{Cu}: \mathrm{Si}=1.37$ \\
\hline & & Dispersoid & $86 \pm 0.65$ & $4.44 \pm 0.59$ & $7.73 \pm 0.11$ & & $0.48 \pm 0.03$ & $1.16 \pm 0.03$ & $0.18 \pm 0.01$ & & $\alpha-\mathrm{AlMnCuSi} ;\left(\tau_{9}\right)\left(\mathrm{Al}_{9}(\mathrm{Mn}, \mathrm{Cu})_{2} \mathrm{Si}\right)$ \\
\hline
\end{tabular}

